\title{
Firm Internal Network, Environmental Regulation, and Plant Death
}

\author{
Jingbo Cui and GianCarlo Moschini
}

Working Paper 18-WP 585

October 2018

\author{
Center for Agricultural and Rural Development \\ lowa State University \\ Ames, lowa 50011-1070 \\ www.card.iastate.edu
}

Jingbo Cui is associate professor, School of Economics and Management, Wuhan University, China. E-mail: jbcui2013@gmail.com

GianCarlo Moschini is professor and Pioneer Chair in Science and Technology Policy, Department of Economics, Iowa State University, Ames, Iowa. E-mail: moschini@iastate.edu

This publication is available online on the CARD website: www.card.iastate.edu. Permission is granted to reproduce this information with appropriate attribution to the author and the Center for Agricultural and Rural Development, lowa State University, Ames, lowa 50011-1070.

Iowa State University does not discriminate on the basis of race, color, age, ethnicity, religion, national origin, pregnancy, sexual orientation, gender identity, genetic information, sex, marital status, disability, or status as a U.S. veteran. Inquiries can be directed to the Interim Assistant Director of Equal Opportunity and Compliance, 3280 Beardshear Hall, (515) 294-7612. 


\title{
Firm Internal Network, Environmental Regulation, and Plant Death
}

\author{
Jingbo Cui and GianCarlo Moschini*
}

This version: October 2, 2018

\begin{abstract}
This paper examines the role of a firm's internal network in determining plant shutdown decisions in response to environmental regulations. Using unique plant-level data for U.S. manufacturing industries from 1990 to 2008, we find evidence that, in response to increasingly stringent environmental regulations at the county level, multi-plant firms do exercise their greater flexibility in adjusting production, relative to single-plant firms. Specifically, in regulated counties, the likelihood of a plant shutting down is higher for multi-plant firms. Moreover, we measure the firm internal network effect at the local, neighborhood, and the wider-area levels, as defined by the number of affiliated plants clustered in different regional levels. Their effects on plant closure decisions for dirty subsidiaries vary with the network level. We further decompose the neighborhood network into those in regulated and unregulated neighborhood counties, and examine how these network metrics are associated with closure decisions of dirty plants affiliated with multi-plant firms. The presence of more sibling plants residing in neighboring counties that are free from regulatory controls are associated with a higher closure probability of dirty plants in a regulated county.
\end{abstract}

Keywords: Agglomeration, Clean Air Act Amendments, Multinationals, Multi-plant firms, Network effects

JEL Classification: F18, Q56, R11

\footnotetext{
*Jingbo Cui (jbcui2013@gmail.com) is Associate Professor in School of Economics and Management, Wuhan University, China. GianCarlo Moschini (moschini@iastate.edu) is Professor and Pioneer Chair in Science and Technology Policy, Department of Economics and Center for Agricultural and Rural Development, Iowa State University. The authors thank Randy Becker and Ron Shadbegian for comments and suggestions. This paper also benefits from discussions with conference participants at 2017 AERE in Pittsburgh, and 2017 EAERE in Athens. Any remaining errors are on our own.
} 


\section{Introduction}

Environmental regulations have long been of considerable policy interest, and remain controversial. Supporters of regulatory controls point to significant health benefits associated with reductions in environmental pollution, while critics blame environmental regulations for productivity drops, job losses, and relocation of manufacturers. For both sides of the argument, a critical question relates to how firms respond to environmental regulation. Empirical contributions in this area have sought to quantify such response (Henderson, 1996; Becker and Henderson, 2000; List et al., 2003b). But the existing literature has paid little attention to the role of a firm's plant structure. Because multi-plant firms may behave differently than single-plant firms, multi-plant firms' decisions about relocation, in response to regulatory controls, may impact the effectiveness of environmental regulations. They also have the potential to play a major role in the dynamics of employment, evolution of regional economies, and restructuring of industry. This is relevant because multi-plant firms account for a large share of U.S. manufacturing activities — as noted by Bernard and Jensen (2007), they employ 78\% of the manufacturing workforce and produce $88 \%$ of the output. Multi-plant firms are also more likely to have emission above the critical level that triggers the need for regulatory compliance (Becker and Henderson, 2000).

In this paper, we follow Bernard and Jensen (2007) by focusing squarely on the probability of plant death, and investigate a channel that was not investigated in their analysis. Specifically, we study the impact of environmental regulation on plant death: the extent to which stringent regulation leads "dirty" plants to exit an industry. In the process, the effects on plant closure of plant attributes, local agglomeration, and some county characteristics are investigated as well. Second, we examine whether multi-plant firms are more or less likely to shut down affiliated plants in response to stringent regulatory controls. Moreover, information on existing plants affiliated with the same headquarter is used to investigate the role of firms' internal network. We measure internal network effects at three different regional levels: local, neighborhood, and the wider area, and we examine how these internal network effects interact with exposure to environmental regulations. We further decompose the neighborhood network into those in regulated and unregulated neighboring counties, and examine how these network measures affect closure decisions of dirty plants (relative to clean ones) affiliated with multi-plant firms.

The particular empirical focus of this paper on the role of multi-plant firms, and their internal structure, is motivated by the theoretical ambiguity of how differently multi-plant firms, relative to 
single-plant firms, may respond to external pressure affecting profitability (Bernard and Jensen, 2007). In our context, multi-plant firms may exercise their greater flexibility in different ways. The availability of multiple plants may reduce the closure probability of a given plant because the firm may abate pollution by reallocating production activities across plants. Alternatively, a multi-plant firm may use plant shutdown as the margin of adjustment to comply with environmental regulation. The costs of a plant's closure are lessened by the ability to shift production activities (and associated jobs) from plants in regulated areas to plants in unregulated areas. The consequences of plant closure are clearly less draconian for multi-plant firms — closure does not imply the end of the firm. The options available to single-plant firms in regulated areas, on the other hand, are more limited.

To carry out the empirical analysis outlined in the foregoing, we compile a unique detailed plantlevel dataset for the U.S. manufacturing sector from 1990 to 2008. To measure plants' exposure to environmental compliance costs, we match plant-level data with county nonattainment/attainment designations under the Clean Air Act Amendments (CAAA) legislation of 1990. By exploiting the spatial and time variations of the CAAA, we estimate the heterogeneous responses of multi-plant firms and single-plant firms to county nonattainment designations. In particular, we propose a triple difference-in-difference model with interaction among a dirty industry dummy, a county regulation indicator, and the regional firm internal network that varies with exposure to environmental pressures.

We obtain some novel and interesting results. First, conditional on plant attributes and county characteristics, we find that nonattainment status under the CAAA legislation leads to some exit of dirty plants in regulated areas. Moreover, we find that multi-plant firms are more likely to close plants in regulated counties as compared to single-plant firms. The closure probability is positively correlated with the plant's distance to the headquarters and the number of existing similar plants affiliated with the same parent company. Second, with respect to firms' internal network effects, we find that the effects of regulation vary with the network level. At the neighborhood level, the larger the number of affiliated plants located in counties sharing borders with the regulated county, the more likely an affiliated dirty plant in the regulated county is to be closed. Third, when conditioning on the neighbor network effect by its exposure to environmental pressures, we find that the presence of more sibling plants residing in neighboring counties that are free from regulatory controls is associated with a higher closure probability of dirty plants in regulated counties. Such internal network effects in regulated neighboring counties are more pronounced in the post-CAAA period of 1990-1999.

This paper contributes to the empirical literature that studies the impact of environmental regulations on firms' site choices (Jeppesen et al., 2002; Brunnermeier and Levinson, 2004). One line 
of studies uses region-level data to examine the effects of regulatory controls on plant births. Using county-level data on plant birth from the U.S. Census Bureau during 1963-1992, Henderson (1996) shows that the ground-level ozone nonattainment regulation leads to the relocation of polluting plants from more to less polluted areas. The follow-up study by Becker and Henderson (2000) further distinguishes the county-level plant births by corporate and nonaffiliated sectors. Whereas the former refers to multi-plant firms, the latter indicates single-plant firms. They find a shift in plant births from the more regulated multi-plant firms to the less regulated single-plant firms. List et al. (2003) revisit the conjecture of a negative correlation between environmental regulation and manufacturing plant birth. Using a county-level dataset for the State of New York from 1980 to 1990, their empirical estimates suggest that pollution-intensive plants adversely respond to county nonattainment designations. Using county-level data, List, McHone, and Millimet (2004) examine the heterogeneous effects of environmental regulations on plant birth decisions for domestic and foreign plants. They find evidence that domestic plants are responsive to environmental regulations, while foreign plants are not. These authors also investigate the impacts of environmental regulation stringency on site choices of relocating plants (List, McHone, and Millimet, 2003).

Another line of inquiry employs plant-level data to examine the effects of regulation stringency on plant location choices. Levinson (1996) considers six environmental regulatory measures for singleplant firms and branches of the 500 largest multi-plant manufacturers, and finds little evidence about the negative impacts of stringent state-level environmental regulations on plant births. List and Co (2000) focus on the state-level environmental regulatory effects on foreign multinational corporations' new plant site choices from 1986 to 1993, and document a negative relationship between environmental stringency and plant birth. Tole and Koop (2010) examine the effects of environmental standards on plant birth decisions of gold mining multinationals across countries.

This paper also adds to the literature in empirical industrial organization that examines the role of firm attributes in determining firms' site choices. ${ }^{1}$ Using plant-level data from the Censuses of Manufactures from 1987 to 1997, Bernard and Jensen (2007) find that plants affiliated with multiplant firms or with U.S.-based multinationals have significantly greater chances of being shutdown, controlling for plant attributes. Similarly, Kneller et al. (2012), based on Japanese plant-level data, find that plants belonging to multi-plant firms are more vulnerable to closure compared with similar single-

\footnotetext{
${ }^{1}$ Related studies focus on relocation decisions of headquarters within the nation (Lovely, Rosenthal, and Sharma, 2005; Davis and Henderson, 2008; Henderson and Ono, 2008; Strauss-Kahn and Vives, 2009) and across countries (Voget, 2011).
} 
plant firms. Moreover, they show that multi-plant multinationals are even more likely to shut down their affiliated plants. By contrast, this paper aims to highlight the role of firms' internal structure in response to stringent environmental controls. As such, our work is also related to recent research examining how firms spread the impacts of local shocks across regions through their internal network of affiliated plants. Local positive investment shocks in Giroud and Mueller (2015) are measured by the introduction of new airline routes between headquarters and affiliated plants, whereas Giroud and Mueller (2017) study local negative employment shocks by exploiting the regional variations in house prices during the Great Recession. In our context, the local shock of interest is the changing stringency of environmental regulation.

The remainder of the paper is organized as follows. Section 2 briefly summarizes the CAAA environmental regulation. Section 3 presents data sources and variables construction. Section 4 provides empirical strategy and descriptive statistics. Section 5 presents results and robustness checks. Section 6 concludes.

\section{Environmental Regulation}

The CAAA of 1990 requires the U.S. Environmental Protection Agency (EPA) to classify each county into pollutant-specific nonattainment and attainment categories, based upon the ambient concentrations of four criteria air pollutants: $\mathrm{SO}_{2}, \mathrm{CO}, \mathrm{O}_{3}$, and TSPs. Each July, the EPA officially reclassifies the pollutant-specific nonattainment/attainment designation for every U.S. county.

The county nonattainment designation serves as an indicator of a plant's exposure to stringent environmental regulations. This exposure varies with both pollutant type and plant characteristics. When a county is designated as nonattainment status for a pollutant, the state where the county is located is required to develop a State Implementation Plan that lays out specific regulations for every major source of the pollutant for the nonattainment county. The stringency of regulatory controls differs between existing and new plants. Whereas the former is subject to reasonably available control technology involving the retrofitting of existing equipment, the latter is exposed to the "lowest achievable emission rate" (LAER), which requires the installation of the cleanest available technology. In sharp contrast, when a county is classified into the attainment category, existing plants are not subject to any technological standards, and new small plants are exempt from the regulation. Only the so-called class-A new polluters, those with the potential to emit over 100 tons per year of a criteria air pollutant, are required to comply with the "best available control technology" standard, a weaker standard than LAER. 


\section{Data}

The data pertain to the U.S. manufacturing sector from 1990 to 2008. We assemble these data from a variety of sources. The plant-level data are from the National Establishment Time Series (NETS) database. ${ }^{2}$ The county-level environmental regulation is obtained from the EPA. The Census Bureau provides the County Business Pattern (CBP) data and the Business Dynamics Statistics (BDS). The former allows us to construct county-by-industry characteristics, while the latter is used to create measures for the industry-level entry and exit rates. The Bureau of Labor Statistics (BLS) supplies the county-level labor force data and the industry-level Producer Price Index (PPI). ${ }^{3}$

The NETS database, developed by Walls and Associates through a joint venture with Dun and Bradstreet, covers over 300 fields and 40 million unique business establishments on a national basis for each year since 1990. The plant-level data in the NETS database include a handful of variables capturing plants' industrial activities, including the number of employees, the value of sales, an indicator of whether or not it exports, and the four-digit SIC industry code. To keep track of each plant, NETS assigns the Data Universal Numbering System (DUNS) number as a unique identifier. It also provides plants' geographic address and (re)location information including the five-digit Federal Information Processing Standard county code, as well as the first and last year in which a plant conducted business. More importantly, the NETS database also provides headquarters information for each plant, specifically the headquarters' names, DUNS numbers, and geographic locations.

To create our unique sample of plants with environmental interests, we link the NETS database to the National Emission Inventory (NEI) of the EPA. ${ }^{4}$ The NEI database contains information about plants that emit criteria air pollutants for all areas of the United States. We match these recorded polluting plants with those collected in the NETS database. For each matched plant, we then find its related plants within the NETS database through the parent company for the entire study period. We restrict our search to those in manufacturing industries. Furthermore, we merge the plant-level data

\footnotetext{
2 NETS data have been used to study issues related to business relocation and business ownership (Rosenthal and Strange, 2003; Kolko and Neumark, 2008, 2010; Neumark, Wall, and Zhang, 2011). Neumark, Wall, and Zhang (2011) provide a detailed description of the NETS and an assessment of the quality of the NETS database along many dimensions, including measurement of employment data, capture of birth, death, and relocation, and linkages of plants to their parent company.

${ }^{3}$ Since 2004, the industry-level data is reported on the three-digit NAICS industry level. We convert the threedigit NAICS industry to the two-digit SIC industry to make it consistent with the data prior to 2004.

${ }^{4}$ Cui, Lapan, and Moschini (2016) discuss the details of the procedure linking the NEI and NETS databases.
} 
with pollutant-specific county nonattainment designations under the CAAA legislation. The Green Book Nonattainment Areas for Criteria Pollutants from the EPA indicates whether only part of a county or the whole county is in nonattainment for each criteria air pollutant. ${ }^{5}$ For each of four criteria pollutants ( $\mathrm{CO}, \mathrm{SO}_{2}, \mathrm{O}_{3}$, and TSPs), we assign a county to the nonattainment category if the whole county or part of the county is designated with nonattainment status. ${ }^{6}$

Figure 1 plots the number of counties with nonattainment status and the number of counties with changed nonattainment status for any criteria air pollutants from 1978 to 2014. ${ }^{7}$ The data are calculated from the EPA Green Book. The number of counties with nonattainment designations drops steadily from over 800 in the late 1970s, when the CAAA was implemented, to around 300 in 2002. Due to the implementation of strict standards for TSPs and ground-level $\mathrm{O}_{3}$, the total number of nonattainment counties jumps back to about 500 around 2004. Moreover, in comparison to our sample period of 1990-2008, there exists substantial variations in county-level nonattainment/attainment designations in both earlier and later sample periods, allowing us to identify the effects of county-level environmental controls on plant closure decisions.

We look closely at the pollutant-specific nonattainment designations. Figure 2 decomposes the information provided by Figure 1 for each individual pollutant. For $\mathrm{SO}_{2}$, variations in nonattainment status are stable during the study period of 1990-2008. For CO, there are substantial variations during the period of 1990-2002. For $\mathrm{O}_{3}$ and TSPs, significant changes in nonattainment designations mainly occur post-CAAA (i.e., 1990-1996) and the late sample period (i.e., 2002-2008). The latter is due to the new implementation of strict standards associated with these two pollutants.

\subsection{Variables}

Table 1 provides a complete list and brief descriptions of variables used in this study, including the outcome variable and other variables of interest that may be influential factors in determining plants' site choices.

\footnotetext{
${ }^{5}$ See http://www.epa.gov/air/oaqps/greenbk/index.html.

${ }^{6}$ The formation of ground-level $\mathrm{O}_{3}$ is a complicated chemical process that involves Volatile Organic Compounds (VOCs) and Oxide of Nitrogen (NOx) when these two react in the presence of sunlight. We classify a county as nonattainment for $\mathrm{O}_{3}$ if it is in nonattainment for $\mathrm{NOx}$ and/or $\mathrm{O}_{3}$, including both onehour and eight-hour standards. In the case of TSPs, a county is defined as TSPs-specific nonattainment when it is in nonattainment for PM10 and/or PM2.5.

${ }^{7}$ For variations in pollutant-specific nonattainment designations at county level, see Figure 3 in the Appendix.
} 
The variable Death is an indicator variable that identifies the year in which a plant shuts down. If a plant is shut down in year $t+1$, the NETS database then puts $t$ in the category of the "last year" when business was still active. Hence, for plant $i$ in year $t$ this variable is defined as:

$\operatorname{Death}_{i t+1}= \begin{cases}1, & \text { if the last active year is } t \\ 0, & \text { otherwise }\end{cases}$

Multi is an indicator variable that identifies whether plant $i$ in year $t$ belongs to a multi-plant firm, (i.e., if there exists at least one other plant that shares the same headquarter DUNS number) it is a single-plant firm otherwise. Note that the multi-plant affiliation status may vary with time due to changes in plant ownership. Hence:

Multi $_{i t}= \begin{cases}1, & \text { if there exists another plant with the same headquarter's DUNS number } \\ 0, & \text { otherwise }\end{cases}$

To assess the effects of being associated with multi-plant firms, we create three distinct metrics of a firm's internal network, based upon the number of affiliated plants across regions. For a plant $i$ operating in industry $j$ and located in county $c$, let $N_{i j c t}^{L}$ denote the number of other plants affiliated with the same firm that also operate in industry $j$ and are located in county $c$ in year $t$. Similarly, let $N_{i j c t}^{N}$ denote the number of other plants affiliated with the same firm that also operate in industry $j$, but which are located in neighboring counties (i.e., counties that share a border with county $c$ ). Let $N_{i j c t}^{W}$ denote the number of other plants affiliated with the same firm that also operate in industry $j$ but are located outside county $c$ and its immediate neighborhood. For single-plant firms, of course, $N_{i j c t}^{L}=N_{i j c t}^{N}=N_{i j c t}^{W}=0$. Given that, we define the local network variable LocalNet $_{i j c t}$, the neighborhood network variable NbrNet $_{i j c t}$, and the wider-area network variable WideNet $_{i j c t}$ as:

$$
\begin{aligned}
& \text { LocalNet }_{i j c t}=\ln \left(1+N_{i j c t}^{L}\right) \\
& \text { NbrNet }_{i j c t}=\ln \left(1+N_{i j c t}^{N}\right) \\
& \text { WideNet }_{i j c t}=\ln \left(1+N_{i j c t}^{W}\right)
\end{aligned}
$$

We further distinguish the firm's internal network in neighboring counties into regulated and unregulated regions. Let $N_{i j c t}^{R N}$ and $N_{i j c t}^{U N}$ denote the number of neighborhood plants associated with the same firm that are located in regulated or unregulated neighboring counties, respectively. Regulated counties here means those designated with at least one pollutant-specific nonattainment status (by 
construction, therefore, $\left.N_{i j c t}^{R N}+N_{i j c t}^{U N}=N_{i j c t}^{N}\right)$. We define the regulated and unregulated neighborhood network variables, respectively, as:

$$
\begin{aligned}
& \text { RegNbrNet }_{i j c t}=\ln \left(1+N_{i j c t}^{R N}\right) \\
& \text { UnregNbrNet }_{i j c t}=\ln \left(1+N_{i j c t}^{U N}\right)
\end{aligned}
$$

The unregulated neighborhood network effect is more likely to trigger the death decision for plant $i$ in the regulated county $c$ than the regulated neighborhood network, because the former requires less cost of resources reallocation from the plant $i$ in the regulated county $c$ to other affiliated plants in the neighborhood counties free from regulation that the latter demands.

For each plant affiliated with a multi-plant firm, the variable Distance $_{i t}$ is defined as the (log) distance of plant $i$ to the firm's headquarters. This variable provides another measure controlling for the impacts of strategic decisions made by a parent company on its affiliated plants. The variable Multindustry ${ }_{i t}$ is defined as the number of two-digit SIC industries in which a firm has associated plants at time $t$.

To control for the possible impacts of ownership changes, we define the variable Takeover ${ }_{i t}$ as an indicator variable that flags the year ownership changes, which for us is defined as when a firm's headquarter's DUNS number changes at time $t$. That is:

$$
\text { Takeover }_{i t}=\left\{\begin{array}{l}
1, \text { if headquarter's DUNS } \\
0, \text { otherwise }
\end{array}\right.
$$

In some cases, plants may switch between multi-plant and single-plant affiliation status due to mergers and acquisitions. Unfortunately, the NETS database does not provide further information about types of ownership changes.

The variable $\operatorname{Reg}_{c t}$ is our measure of a plant's environmental regulatory pressure, which we define as an indicator variable that denotes a county designated as having nonattainment status for at least one of the four air pollutants in year $t$. That is:

$$
\operatorname{Reg}_{c t}= \begin{cases}1, & \text { if county } c \text { is nonattainment for at least one criteria air pollutants } \\ 0, & \text { otherwise }\end{cases}
$$

This regulation variable is also noted as "Any NA" in what follows. To check the robustness of results, we consider pollutant-specific nonattainment designations as alternative measures by analogously defining the variable $\mathrm{Reg}_{p c t}$ separately for each pollutant $p \in\left\{\mathrm{SO}_{2}, \mathrm{CO}, \mathrm{O}_{3}, \mathrm{TSP}\right\}$. 
Let $N_{i j c t}^{A}$ denote the number of existing plants located in the same county and industry as plant $i$, but outside of the firm's internal network. Then the variable $\operatorname{Agglomeration}_{i j c t}=\ln \left(1+N_{i j c t}^{A}\right)$ is used to proxy for local agglomeration.

To identify the role of firms' internal network in manufacturing site choices, we also add a handful of plant characteristics controls. Both existing theoretical and empirical studies suggest that plant age plays an important role in determining plant death. We define Age as plant years of operation, specifically as the difference between the current year and the first recorded NETS year, starting from 1990. Plants that are in their first recorded year are given an age of one. Plant Size, measured by the $\log$ number of employees, is included as well. In addition, plants' log values of deflated sales per labor is added as a raw measure for Labor productivity at the plant level.

As predicted by Melitz-type trade models (Melitz, 2003), productive plants are, ceteris paribus, more likely to export than lower productivity plants due to the interaction between heterogeneous productivity and fixed costs of exporting. This positive correlation between export decision and productivity has been documented in the empirical trade work (Bernard and Jensen, 2004). In addition, the literature examining heterogeneous firms and outsourcing also suggests causality in high productivity and outsourcing decisions (Helpman, Melitz, and Yeaple, 2004; Tomiura, 2007). To further control unobservable productivity, we include an Export Status indicator and Foreign Ownership indicator. The former equals one when a plant exports and zero otherwise, while the latter takes a value of one if a plant is owned by a foreign firm and zero otherwise. These two binary variables are time-invariant, as provided in the NETS database.

For robustness, we further control for industry and geographic factors that may cause variations in plants' shutdown decisions. The measure of county-level tax rates is the median real estate taxes by county in 2005 obtained from the American Community Survey (ACS). Another county-level variable is road density, which is measured by the road length of six different road categories per land area. ${ }^{8}$ This variable helps proxy the effects of local infrastructure on location decisions of manufacturers. To examine the local labor costs over the study period, we account for the county-level unemployment

\footnotetext{
8 The ArcGIS provides a detailed U.S. road map covering from all interstate highways to important local roads. This map defines six road categories: (1) freeway or other major road, (2) major road less important than a freeway, (3) other major road, (4) secondary road, (5) local connecting road, and (6) important local road. We calculate the county-level road length, using the tool box of "intersect" in the ArcGIS software. This tool box helps us compute the length of each road cut by county boundary. For each county, we then add up the road length by six different road categories with equal weights for all categories except the interstate highway, which includes two-way traffic.
} 
rate from the BLS. We also construct industry-by-county wage rate based on the ratio of annual payroll and employment.

The magnitude of sunk entry costs is important in determining the steady-state equilibrium rate of firm birth and death within an industry. In attempt to measure the unobserved entry costs, the minimum of industry entry and exit rates used in Bernard and Jensen (2007) is implemented in the

regression. That is, EntryCost ${ }_{j t}=1-\min \left\{\right.$ entryrate $_{j t}$, exitrate $\left._{j t}\right\}$. The entry and exit rates computed from the BDS are measured at the three-digit SIC industry level. Finally, to control for unobserved industry heterogeneity, we include a full set of industry linear trends. State linear trends are also added to absorb unobservable state characteristics varying with time.

\subsection{Descriptive Statistics}

Our data sample is an unbalanced panel with more than 1.2 million plant-by-year observations over the 1990-2008 period. These observations are obtained from 153,582 unique plants affiliated with 44,069 unique headquarters.

Table 2 provides summary statistics for the main variables used in the analysis. The value of sales is deflated by the two-digit SIC industry PPI. Approximately $80 \%$ of observations are plants affiliated with multi-plant firms, while the remaining are owned by single-plant firms. The last two columns of Table 2 summarize the mean differences between multi-plant and single-plant status across plant characteristics. Plants that belong to multi-plant firms are larger than those with single-plant firms in terms of larger value of sales and more employees. However, relative to the latter, plants of multiplant firms have lower labor productivity measured by deflated sales per worker. When location decisions are concerned, plants affiliated with multi-plant firms have higher death and takeover rates than those with single-plant firms. In addition, compared with single-plant firms, multi-plant firms have a relatively higher fraction of plants owned by foreign companies, but a lower fraction of exporting plants. When it comes to the exposure to environmental regulations, the fraction of singleplant firms in counties that are in nonattainment status for at least one pollutant is larger than that of multi-plant firms residing in nonattainment counties. This result holds for all four different pollutantspecific regulations, except $\mathrm{SO}_{2}$ nonattainment designation.

Table 3 provides mean values for plant attributes by firm structure and county nonattainment status. For instance, plants being part of single-plant firms and located in any nonattainment counties, on average, have 77 employees. Several interesting points arise from Table 3. First, for each type of firm ownership, either single-plant or multi-plant, the number of plants located in nonattainment 
counties is larger than that residing in counties free from environmental regulations. This indicates that a substantial fraction of plants are subject to regulatory burdens. Second, plant size differs by exposure to environmental pressures. Regardless of multi-plant status, plants residing in nonattainment counties are younger and smaller in size (in terms of the number of employees), but have higher labor productivity (deflated sales per worker) than those exempt from environmental burdens. Third, regardless of multi-plant ownership, plants located in nonattainment counties have higher death rate, but slightly lower takeover rates than those in attainment counties. When comparing plants located in nonattainment counties, but differing in multi-plant status, multi-plant firms tend to have larger death and takeover rates relative to similar single-plant firms. Lastly, multi-plant firms have, on average, more subsidiaries located in nonattainment counties than in attainment counties.

To further investigate plant death rates by multi-plant status and environmental exposure, we compute average plant death rate at county-level by multi-plant status for each year. For each countyyear pair, death rate is computed as the number of plant deaths divided by the number of existing plants across multi-plant status. Then, for each year we take the mean value of county-level death rates by nonattainment status. Figure 4 shows that, regardless of environmental pressures, multi-plant firms have much higher death rates than single-plant firms over our study period of 1990-2008. When it comes to regulatory exposure, death rates of plants located in nonattainment and attainment counties follow a similar pattern. Moreover, plants located in nonattainment counties have modestly higher death rates than those residing in attainment counties across years.

\section{Empirical Models}

We seek to examine whether, in response to local stringent environmental controls, multi-plant firms are more or less likely to close an affiliated plant in regulated counties than single-plant firms. Also, among multi-plant firms, we are interested in identifying the heterogeneous effects of the firm's internal network characteristics on closure decisions of affiliated dirty plants that are exposed to environmental pressures. Moreover, we investigate how the structure of firms' internal network in terms of exposure to environmental pressures, affects the shutdown decisions of dirty plants relative to clean plants in response to tightened local regulatory controls.

To identify the heterogeneous effects of CAAA regulation on plant closure decisions, we estimate a series of probit models that represent the probability of plant death. The general structure of these probit models can be represented as follows: 


$$
\operatorname{Prob}\left(\operatorname{Death}_{i t}\right)=\Phi\left(X_{i t} \beta+Z_{i t} \theta+\Lambda_{c j t}\right)
$$

The outcome indicator variable Death $_{i t}$ was defined earlier, and $\Phi(\cdot)$ denotes the cumulative distribution function of the normal distribution. As noted earlier, $i$ indexes a plant, $j$ indicates the industry of said plant, $c$ is the county where the plant is located, and $t$ denotes the observation year. In equation (1), $X_{i t}$ is a vector of regulatory and network variables that we wish to single out in our analysis, $Z_{i t}$ is a vector of other explanatory and control variables (including plant characteristics), and $\Lambda_{c j t}$ is a vector of fixed effects that control for county, industry, and time factors common to all plants within the same county (such as county-level regulation, the measure of agglomeration economies, and industry-by-county wage rate). The various models considered below have the structure of equation (1) and differ in the details of the specification of the term $X_{i t} \beta$.

\subsection{Multi-plant vs. Single-plant Death}

We explore the role of firms' internal networks in determining plants' responses to stringent environmental regulations, controlling for plant, county, and industry characteristics. We test whether a multi-plant firm, in response to tightened environmental controls, is more or less likely to shut down its affiliated plants than a single-plant firm. Moreover, we distinguish firms' internal network effects with local agglomeration by utilizing the variables discussed earlier. We also consider how plant attributes, including size, age, labor productivity, and other characteristics, are related to their likelihood of shutting down. The county-level characteristics are also included to control for confounding factors affecting the closure decisions of plants. The structural part of the probit model for this analysis can be represented as

$$
X_{i t} \beta \equiv \beta_{11} \operatorname{Reg}_{c t-1} \times M u l t i_{i t-1}
$$

Note that because the EPA determination of nonattainment status is made in July of any given year, our presumption is that the shutdown probability in year $t$ is related to the status in place at the beginning of the year (which was determined in July of year $t-1$ ). The parameter of interest, $\beta_{11}$, is the coefficient for the interaction term between the regulation variable $\operatorname{Reg}_{c t}$ and multi-plant ownership dummy $M u l t i_{i t}$. This parameter captures the heterogeneous regulatory impacts on multiplant closure decisions relative to those with single-plant firms, controlling for local agglomeration 
effects and county and industry characteristics.

\subsection{Firm Internal Network}

As sketched in a heuristic map in Figure 3, plants affiliated with the same parent company are located across counties; and hence, in principle, are subject to variations in local environmental pressures. When considering the possibility of reallocating resources from plants in regulated counties to affiliated plants in unregulated counties, reallocation costs may vary with the distance between the regulated plant and its affiliated plants. The distribution of sibling plants in different regional levels may have different impacts on the probability of shutting down a plant in regulated counties and reallocating its production resources to avoid regulatory compliance. As noted, we consider three regional measures for firms' internal network (local, neighborhood, and the wider area).

To tease out the regulatory impact on closure decisions of dirty plants, we further define dirty plants as those in a dirty industry (i.e., industries that are known to be heavy emitters of criteria air emissions). The classification of dirty industry is pollutant-specific and based on Greenstone (2002), and described in Table 4. We denote Dirty $j$ as a dirty industry indicator if the industry is classified as heavy emitters of any criteria air pollutants in the list of $\mathrm{SO}_{2}, \mathrm{CO}, \mathrm{O}_{3}$, and TSPs. For each three regional network measures, we examine the firm's internal network effect on closure decisions for affiliated dirty plants located in nonattainment counties by interacting the regional network variables with the county regulatory control variable and dirty industry indicator. The county regulatory controls and firm internal network measures are implemented in one-year lagged fashion, allowing relocation decisions for dirty plants in the current year to respond to the stringent local environmental regulation in the past year. Because a firm may have plants located in local, neighborhood, and wider areas, their joint network effects may influence site choices of affiliated dirty plants in regulated counties. We add all three network effects and their interaction terms into one specification by representing the structural part of the probit model as follows:

$$
\begin{aligned}
X_{i t} \beta \equiv & \beta_{21} \text { Dirty }_{j} \times \operatorname{Reg}_{c t-1} \times \text { LocalNet }_{i j c t-1}+\beta_{22} \text { Dirty }_{j} \times \operatorname{Reg}_{c t-1} \times \text { NbrNet }_{i j c t-1} \\
& +\beta_{23} \text { Dirty }_{j} \times \operatorname{Reg}_{c t-1} \times \text { WideNet }_{i j c t-1}
\end{aligned}
$$

The coefficients of interest, $\left(\beta_{21}, \beta_{22}, \beta_{23}\right)$, measure the effects of different regional networks by comparing location responses of dirty plants with those of clean plants when both types of plants are located in counties with strict environmental regulations. One may expect that $\left(\beta_{21} \neq \beta_{22} \neq \beta_{23}\right)$, 
indicating the heterogeneous regional firm internal network effects on closure choices of dirty plants relative to clean plants in response to local regulatory compliance.

Next, consider a plant $i$ that is located in a nonattainment county $c$, as depicted in the lower panel of Figure 3. To avoid environmental compliance, the parent company of plant $i$ may consider shutting it down. The probability of shutting down plant $i$ may be influenced by the number of affiliated plants located in counties that share borders with county $c$-in particular, the number of affiliated plants located in unregulated neighboring counties. Thus, we consider a variant specification with the joint effects of different regional networks varying with exposure to regulations, as follows,

$$
\begin{aligned}
X_{i t} \beta \equiv & \beta_{31} \text { Dirty }_{j} \times \operatorname{Reg}_{c t-1} \times \text { RegNbrNet }_{i j c t-1}+\beta_{32} \text { Dirty }_{j} \times \text { Reg }_{c t-1} \times \text { UnregNbrNet }_{i j c t-1} \\
& +\beta_{33} \text { Dirty }_{j} \times \operatorname{Reg}_{c t-1} \times \text { RegWideNet }_{i j c t-1}+\beta_{34} \text { Dirty }_{j} \times \text { Reg }_{c t-1} \times \text { UnregWideNet }_{i j c t-1}
\end{aligned}
$$

The coefficients $\left(\beta_{31}, \beta_{32}, \beta_{33}, \beta_{34}\right)$ capture how the regional firm's internal network in regulated and unregulated counties would affect the shutdown probability of an affiliated dirty plant relative to that of a sibling clean plant, both of which are located in the same regulated county $c$. One may expect that $\left(\beta_{31} \neq \beta_{32} \neq \beta_{33} \neq \beta_{34}\right)$, suggesting the different effects of regional network by the variations in environmental exposure. Moreover, one may expect $\left(\beta_{32}>\beta_{34}>0\right)$, indicating that the regional network in unregulated counties provides a potential channel of reallocating resources from dirty plants in regulated counties to sibling plants in nearby unregulated counties. In addition, the effects of regional firms' internal networks on plant death declines as the distance of the network to the regulated plant rises. The signs of $\left(\beta_{31}, \beta_{33}\right)$, however, are ambiguous, because resource reallocation from one dirty plant in a regulated county to its siblings in other regulated counties would not help the firm escape from environmental compliance.

\section{Results}

We start by presenting results on whether multi-plant firms are more likely to close a plant than singleplant firms in response to local environmental regulatory control. We then show how regional firms' internal networks are involved in affecting closure decisions of dirty plants in relation to clean plants. The effects of regional firms' internal network interacting with exposure to environmental pressures on plant death are presented. A series of robustness checks on model specifications, sample, and alternative measures for firms' internal networks are considered. 


\subsection{Multi-plant vs. Single-plant Death}

Table 5 reports estimation results for the multivariate probit models of plant death conditional on plant and county characteristics. Whereas columns $1-4$ are based on the full sample, but vary with the choices of fixed effects as noted at the bottom of the table, the last two columns examine the subsamples for multi-plant and single-plant firms only, respectively. In all columns, standard errors clustered at county level are reported in parentheses, and industry is measured by the three-digit SIC.

The results strongly support the hypothesis that plants' shutdown decisions are positively associated with multi-plant status. Specifically, we find positive and statistically significant coefficients for multi-plant affiliation status in all columns of Table 5. These estimates consistently suggest that being affiliated with multi-plant firms significantly increases the probability of plant death at the margin by about two percentage points. This result matches findings by Bernard and Jensen (2007), who also conclude that multi-plant firms have greater chances of closing a plant relative to singleplant firms, conditional on plant and county characteristics.

Moreover, we are interested in the effects of environmental regulations on plant deaths. When splitting the data into sub-sample by multi-plant status, as shown in the last two columns of Table 5, there are positive coefficients for the regulatory control. This positive coefficient is statistically significant at the $1 \%$ level for the multi-plant sub-sample, while it is not statistically significant at any conventional level for the single-plant sub-sample. The environmental controls have significant impacts on the closure probability of plants affiliated with multi-plant firms, but not with single-plant firms. The main focus of this paper is on the heterogeneous responses between multi-plant and singleplant firms when both groups are subject to local regulatory controls. This heterogeneous environmental response is captured by the coefficient for the interaction term between multi-plant status and regulatory measure. In all columns with full sample, this coefficient is positive and statistically significant at the $1 \%$ level. Controlling for plant attributes and county characteristics, we find substantial differences in plant closure decisions in response to stringent regulations between multi-plant and single-plant firms. For plants located in nonattainment counties, and hence encountering environmental compliance, a plant that is part of a multi-plant firm has a higher shutdown probability than a comparable single-plant firm. This finding suggests that, in compliance with strict controls, multi-plant firms are more likely to use the plant closure margin to deal with

\footnotetext{
${ }_{9}$ Alternative standard errors clustered at industry, county, and headquarter level are considered, but do not alter our main conclusions.
} 
environmental compliance.

The effects of the firm's internal network on plant death are examined next. We consider two alternative measures: the (log) distant of a plant to its headquarters, and the (log) number of affiliated plants located in the same county and in the same industry at time t. There are consistently positive and statistically significant coefficients for these two variables across all columns in Table 5 . When a plant is located further away from its parent company, it is more likely to be shut down, as suggested by the positive and statistically significant coefficient for the distance variable. In addition, we find strong evidence supporting the positive effect of firms' internal networks on plant death. The larger the number of a firm's affiliated plants in the same county, the higher probability an affiliated plant would be closed. We also add a control for the number of industries that a firm's headquarters are involved with. This coefficient is consistently positive and statistically significant at the $1 \%$ level in all specifications. Hence, we find that the higher the number of sub-sectors in which the headquarters have affiliated plants, the higher the chance an affiliated plant will be closed.

When closely inspecting the relationship between plant attributes and closure likelihood, we find negative and statistically significant coefficients for plant size, labor productivity, and age, indicating that the probability of plant closure substantially decreases with these plant attributes. This result implies that headquarters are more likely to shut down low-productivity and small-size plants, and that older plants are more resilient to exiting pressure. We next consider whether exporters or multinational firms are related to the probability of plant closure. As expected, the negative and statistically significant coefficient shows that exporting plants have lower probability of exit (by roughly 1.6 percentage points). This result is consistent with predictions arising from the new-new trade theory with heterogeneous firms (e.g., Melitz, 2003), showing that exporters are less likely to exit the domestic market than their competing non-exporters. The effect of foreign ownership shows that plants owned by foreign firms are less likely to be closed. We further examine the effects of changes in plant

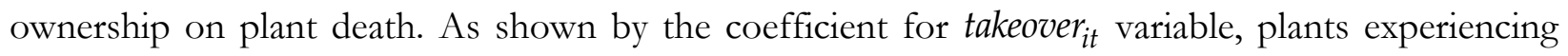
changes in ownership have higher shutdown probability. This positive coefficient is statistically significant at the $1 \%$ level for all specifications in Table 5. The negative effect of the ownership changes on plant closure probability is about two percentage points. One possible explanation for this effect is that plants that have changed their ownerships are those that may behave poorly in the first place, and hence are vulnerable to negative economic shocks.

When it comes to the effects of county characteristics on plants' shutdown likelihood, the results vary with the level of fixed effects included in the specification. When state or industry fixed effects 
are present, the coefficient for local agglomeration variable is positive and statistically significant at the $1 \%$ level, while the coefficient for local income is positive, but not significant at any conventional levels. This piece of evidence suggests that the agglomeration effect raises plant death probability through competition in local markets. Property tax and industry county wage rate are measures for production costs. The estimated coefficients for these two county-level controls are positive and statistically significant at the $1 \%$ level. This result implies that higher property tax and wage rates raise plants' production costs, thereby increasing the probability of death. Similarly, both the county-level unemployment rate and road density also display positive coefficients with statistical significance at the $1 \%$ level. The former result suggests that local unemployment rates lead to plant closure probability, while the latter indicates that local infrastructure (perhaps surprisingly) contributes to the exit of plants. Lastly, the industry sunk costs, measured by the entry-exit rates as in Bernard and Jensen (2007), have negative coefficients. When the industry fixed effects are controlled to absorb the industry-level confounding unobservable, the coefficient for the industry sunk cost does not have statistical significance at any conventional levels, lending little support on the impacts of entry costs on plant exit.

\subsection{Regional Firm Internal Network Effects}

Table 6 reports the estimated probit models for specification (3). All controls listed in column 5 of Table 5 are included, but their coefficients are not reported in this table to save space. All columns also include a set of year fixed effect, three-digit SIC industry linear trends and state linear trends. Standard errors are clustered at count level.

For all three regional networks-local $\left(\right.$ LocalNet $\left._{i j t-1}\right)$, neighborhood $\left(\operatorname{NbrNet}_{i j c t-1}\right)$, and wider area $\left(\right.$ WideNet $\left._{i j t-1}\right)$-we document consistently positive impacts of regional networks interacting with the dirty industry dummy and county regulation on plant death, as shown in columns 1-3 of Table 6. Among all three estimated regional network effects, the neighborhood network has the largest positive effect, which is statistically significant at the 5\% level. Local and wider-area network effects, on the other hand, are not statistically significant at conventional levels. The results are essentially unchanged when all three regional network effects are considered simultaneously, as presented in column 4 of Table 6. The effect that stands out is that associated with the neighborhood network. The presence of sibling plants in neighboring counties increases the probability of a dirty plant being shutdown in a regulated county. The local network does not exhibit the same effect: shifting resources between plants that are subject to the same regulatory pressure does not help the firm's environmental compliance 
strategy.

\subsection{Firm Internal Network Effects by Environmental Pressures}

We further split neighborhood and wider-area networks into those in regulated areas and unregulated areas. Table 7 provides the estimated probit models for plant death based on specification (4). In column 1 of Table 7, we document a positive coefficient of the interaction term among the dirty industry dummy, county regulation indicator, and neighbor network in regulated counties. This positive effect is statistically significant at the $1 \%$ level, indicating that as more affiliated plants are located in neighboring counties without environmental pressures, a parent company would be more likely to close a dirty plant in the regulated county to deal with environmental compliance. Conversely, we find little evidence of a regulated neighbor network effect. When there are some sibling plants residing in neighboring counties also with environmental pressures, then these plants are also exposed to environmental controls and thus are not attractive for the purpose of reallocating production resources in order to lessen the cost of environmental compliance.

As the firm's internal network moves to the circle outside of neighboring counties, the impact of the regional network on plant closure is weakened. Column 2 of Table 7 shows a positive (but insignificant) coefficient for the wider network in unregulated areas, and a negative coefficient for the wider network in regulated areas. The latter is significant at the $1 \%$ level. Affiliated plants in unregulated areas that are located further away from dirty plants in regulated counties have a weak or no impact on closure decisions. Conversely, when the firm also faces environmental pressure in the wider area, then this reduces the odds of plant closure in a given regulated county (the associated coefficient in Table 7 is negative and statistically significant). The coefficients for the specification that includes both neighborhood and wider area networks are reported in column 3 of Table 7 . The results are essentially the same as in columns 1 and 2.

\section{$5.4 \quad$ Robustness}

To check the robustness of our results, we re-conduct regression analysis based upon specification (4), while considering different sample periods, pollutant-specific nonattainment designations, and an alternative model specification with more controls of fixed effects.

\subsubsection{Sample period}

Figure 1 depicts the number of counties per year from 1978 to 2014 with changed nonattainment/ 
attainment designations. During the sample period of 1990-2008, a substantial number of counties changed designation status during the early 1990s and the mid-2000s. The former is due to the postCAAA period, while the latter is because of new and strict standards for TSPs and ground-level $\mathrm{O}_{3}$ implemented around 2004. Thus, we split the whole sample period into two parts: the post-CAAA period of 1990-1999 and the new standard period of 2000-2008. For each restricted sample period, we re-conduct the probit model in specification (3). Table 8 reports the corresponding results. In the post-CAAA period, as shown in columns 1-3 of Table 8, the positive effect of firms' internal networks on plant death in unregulated neighboring counties remains statistically significant at the $1 \%$ level. During this period, in response to local regulatory control, headquarters are more likely to close dirty plants and shift production to other affiliated plants in the nearby neighboring counties, which are free from environmental regulations. Moreover, a negative and statistically significant coefficient for firms' internal network in wider areas without environmental pressures is again found. With more siblings in regulated areas further away from the focal dirty plant, the likelihood of shutting down in response to local environmental compliance declines.

In the new standard period, as shown in columns 4-6 of Table 8, coefficients of neighbor network in unregulated counties are positive and statistically significant at the $5 \%$ level, lending support to the conclusion that the unregulated neighbor network does impact plant death. There is little evidence on the negative effects of the wider network in regulated areas on closure decisions of dirty plants.

\subsubsection{Pollutant-Specific Regulation}

Figure 2 depicts the number of counties with changed designation status for each criteria air pollutant under the CAAA. The pattern varies with pollutant. The changes of $\mathrm{SO}_{2}$-specific status mainly occur in the later 1970s, and are stable during the sample period of 1990-2008. For CO, there exist substantial changes in designations during the post-CAAA period of 1990-2002. For $\mathrm{O}_{3}$ and TSPs, variations in designations mainly appear in the early 1990s and mid-2000s.

We consider a pollutant-specific regulation and pollutant-specific dirty industry indicator. Let Dirty $_{p}$ be pollutant-p-specific dirty industry dummies, following Greenstone (2002). Let Reg cpt-1 denote pollutant-p-specific county nonattainment status at $\mathrm{t}-1$. For each pollutant $p \in\left\{\mathrm{SO}_{2}, \mathrm{CO}, \mathrm{O}_{3}\right.$, TSPs $\}$, the following variant specification is considered: 


$$
\begin{aligned}
X_{i t} \beta \equiv & \beta_{41} \text { Dirty }_{p} \times \operatorname{Reg}_{c p t-1} \times \operatorname{RegNbrNet}_{i j c t-1}+\beta_{42} \text { Dirty }_{p} \times \text { Reg }_{c p t-1} \times \text { UnregNbrNet }_{i j c t-1} \\
& +\beta_{43} \text { Dirty }_{p} \times \operatorname{Reg}_{c p t-1} \times \text { RegWideNet }_{i j c t-1}+\beta_{44} \text { Dirty }_{p} \times \text { Reg }_{c p t-1} \times \text { UnregWideNet }_{i j c t-1}
\end{aligned}
$$

where the firm's internal network variables are defined as before.

Table 9 reports the probit model estimates on plant death during the whole sample period of 1998-2008. Columns vary with pollutant type. In response to $\mathrm{SO}_{2}$-specific regulation, the wider network in unregulated areas raises the shutdown probability of dirty plants relative to that of clean plants. This corresponding network effect in unregulated neighboring counties is negative but statistically not significant. When it comes to $\mathrm{CO}$ - and $\mathrm{O}_{3}$-specific nonattainment designations, we find positive coefficients for the network in unregulated neighboring counties. These positive estimates are statistically significant at the $10 \%$ level for $\mathrm{CO}$ and the $1 \%$ level for $\mathrm{O}_{3}$. This finding suggests that dirty polluters may respond to regulations by shifting resources to other affiliated plants in the unregulated neighboring counties and then close dirty plants that are subject to $\mathrm{CO}-$ or $\mathrm{O}_{3-}$ specific regulatory controls. For the wide area network in regulated areas, the effect is negative and statistically significant for $\mathrm{O}_{3}$-specific nonattainment regulation. Lastly, for TSPs the significant effect that emerges concerns the regulated neighboring counties: the presence of sibling plants in such counties actually reduces the shutdown probability of a dirty plant facing regulatory pressure.

\subsubsection{Alternative Model Specifications}

Instead of the probit model, here we estimate a linear probability model of plant death using ordinary least square (OLS) regressions that include additional fixed effects (for the county or for the plant). By controlling for unobserved county or plant heterogeneity, this alternative model specification further helps tease out the causal effects for the role of the firm internal network on closure decisions

of dirty plants in response to local tough environmental controls. Table 10 presents the OLS results of the triple interaction terms among the dirty industry dummy, one-year lagged county regulation, and one-year lagged firm internal network.

Controlling for county or plant fixed effects, the estimated coefficients for the triple interaction of firm internal network in unregulated neighboring counties are positive and statistically significant, while the estimated coefficient for the triple interaction of firm internal network in regulated nonneighboring counties are negative and statistically significant in most cases. These OLS estimates are therefore largely consistent with those reported for the probit models. 


\section{Conclusion}

In this paper we examine the role of firm structure in determining plant death in response to increasingly stringent environmental regulation while controlling for plant attributes, headquarter network, local agglomeration, and county characteristics. We find strong evidence of heterogeneous responses to the stringent environmental control between multi-plant and single-plant firms. Multiplant firms have greater flexibility to respond to strict environmental controls. We find that plant closure is a significant margin of adjustment for multi-plant firms. They are more likely to close affiliated plants located in counties with stringent environmental regulations-in particular, they are likely to shut down plants located far away from the parent company or locations with many other similar plants in the same county. Moreover, in response to regulatory pressure, the structure of a firm's internal network matters. Multi-plant firms are more likely to close a plant in regulated counties when they possess affiliated plants in counties neighboring the regulated county. This effect is mainly driven by the firm's internal network in unregulated neighboring counties, which is measured by the number of affiliated plants in neighboring counties free from environmental regulations.

This paper extends our understanding on the heterogeneous regulatory impacts of environmental regulation on firms' production activities. Our results show that multi-plant firms do exercise their greater flexibility in adjusting to tough environmental regulations, relative to single-plant firms. Increasing awareness of this fact makes the design and assessment of environmental policies more challenging. On the one hand, similar to emission leakage across borders, we may experience the unintended consequence of emissions leakage across affiliated plants through the internal network of multi-plant firms. On the other hand, the ability of firms to shift production activities across plants can play a positive role by providing a cost-efficient avenue for environmental compliance, one that can reduce emissions while minimizing the impact on production and employment. Inevitably in such circumstances, the impacts of policy may contribute to spatial inequality, echoing concerns similar to those arising from the impact of trade liberalization and the role of multinational firms. 


\section{References}

Becker, R., Henderson, V., 2000. Effects of Air Quality Regulations on Polluting Industries. Journal of Political Economy 108 (2), 379-421.

Bernard, A. B., Jensen, J. B., 2004. Why Some Firms Export. The Review of Economics and Statistics 86 (2), $561-569$.

Bernard, A. B., Jensen, J. B., 2007. Firm Structure, Multinationals, and Manufacturing Plant Deaths. The Review of Economics and Statistics 89 (2), 193-204.

Brunnermeier, S. B., Levinson, A., 2004. Examining the Evidence on Environmental Regulations and Industry Location. The Journal of Environment \& Development 13 (1), 6-41.

Cui, J., Lapan, H., Moschini, G., 2016. Productivity, Export and Environmental Performance: Air Pollutants in the United States. American Journal of Agricultural Economics 98(2), 447-467.

Davis, J. C., Henderson, J. V., 2008. The Agglomeration of Headquarters. Regional Science and Urban Economics 38 (5), 445-460.

Giroud, X., Mueller, H. M., 2015, Capital and Labor Reallocation within Firms, the Journal of Finance, 70(4): 1767-1804.

Giroud, X., Mueller, H. M., 2017, Firms’ Internal Networks and Local Economic Shocks, NBER Working Paper No 23176.

Greenstone, M., 2002. The Impacts of Environmental Regulations on Industrial Activity: Evidence from the 1970 and 1977 Clean Air Act Amendments and the Census of Manufactures. Journal of Political Economy 110 (6), 1175-1219.

Helpman, E., Melitz, M. J., Yeaple, S. R., 2004. Export Versus FDI with Heterogeneous Firms. American Economic Review 94 (1), 300-316.

Henderson, J. V., 1996. Effects of Air Quality Regulation. American Economic Review 86 (4), 789-813.

Henderson, J. V., Ono, Y., 2008. Where do Manufacturing Firms Locate Their Headquarters? Journal of Urban Economics 63 (2), 431-450.

Jeppesen, T., List, J. A., Folmer, H., 2002. Environmental Regulations and New Plant Location Decisions: Evidence from A Meta-Analysis. Journal of Regional Science 42 (1),19-49.

Kneller, R., McGowan, D., Inui, T., Matsuura, T., 2012. Closure within Multi-plant Firms: Evidence from Japan. Review of World Economics 148 (4), 647-668.

Kolko, J., Neumark, D., 2008. Changes in the Location of Employment and Ownership: Evidence from California. Journal of Regional Science 48 (4), 717-744.

Kolko, J., Neumark, D., 2010. Does Local Business Ownership Insulate Cities from Economic Shocks? 
Journal of Urban Economics 67 (1), 103-115.

Levinson, A., 1996. Environmental Regulations and Manufacturers' Location Choices: Evidence from the Census of Manufactures. Journal of Public Economics 62 (1-2), 5-29.

List, J. A., Co, C. Y., 2000. The Effects of Environmental Regulations on Foreign Direct Investment. Journal of Environmental Economics and Management 40 (1), 1-20.

List, J. A., McHone, W. W., Millimet, D. L., 2003. Effects of Air Quality Regulation on the Destination Choice of Relocating Plants. Oxford Economic Papers 55 (4), 657-678.

List, J. A., McHone, W. W., Millimet, D. L., 2004. Effects of Environmental Regulation on Foreign and Domestic Plant Births: Is There a Home Field Advantage? Journal of Urban Economics 56 (2), 303-326.

List, J. A., Millimet, D. L., Fredriksson, P. G., McHone, W. W., 2003. Effects of Environmental Regulations on Manufacturing Plant Births: Evidence from a Propensity Score Matching Estimator. The Review of Economics and Statistics 85 (4), 944-952.

Lovely, M. E., Rosenthal, S. S., Sharma, S., 2005. Information, Agglomeration, and the Headquarters of U.S. Exporters. Regional Science and Urban Economics 35 (2), 167-191.

Melitz, M., 2003. The Impact of Trade on Intra-Industry Reallocations and Aggregate Industry Productivity. Econometrica 71 (6), 1695-1725.

Neumark, D., Wall, B., Zhang, J., 2011. Do Small Businesses Create More Jobs? New Evidence for the United States from the National Establishment Time Series. The Review of Economics and Statistics 93 (1), 16-29.

Rosenthal, S. S., Strange, W. C., 2003. Geography, Industrial Organization, and Agglomeration. The Review of Economics and Statistics 85 (2), 377-393.

Strauss-Kahn, V., Vives, X., 2009. Why and Where do Headquarters Move? Regional Science and Urban Economics 39 (2), 168-186.

Tole, L., Koop, G., 2010. Do Environmental Regulations Affect the Location Decisions of Multinational Gold Mining Firms? Journal of Economic Geography.

Tomiura, E., 2007. Foreign Outsourcing, Exporting, and FDI: A Productivity Comparison at the Firm Level. Journal of International Economics 72 (1), 113-127.

Voget, J., 2011. Relocation of Headquarters and International Taxation. Journal of Public Economics 95 (9), 1067-1081. 
Figures and Tables

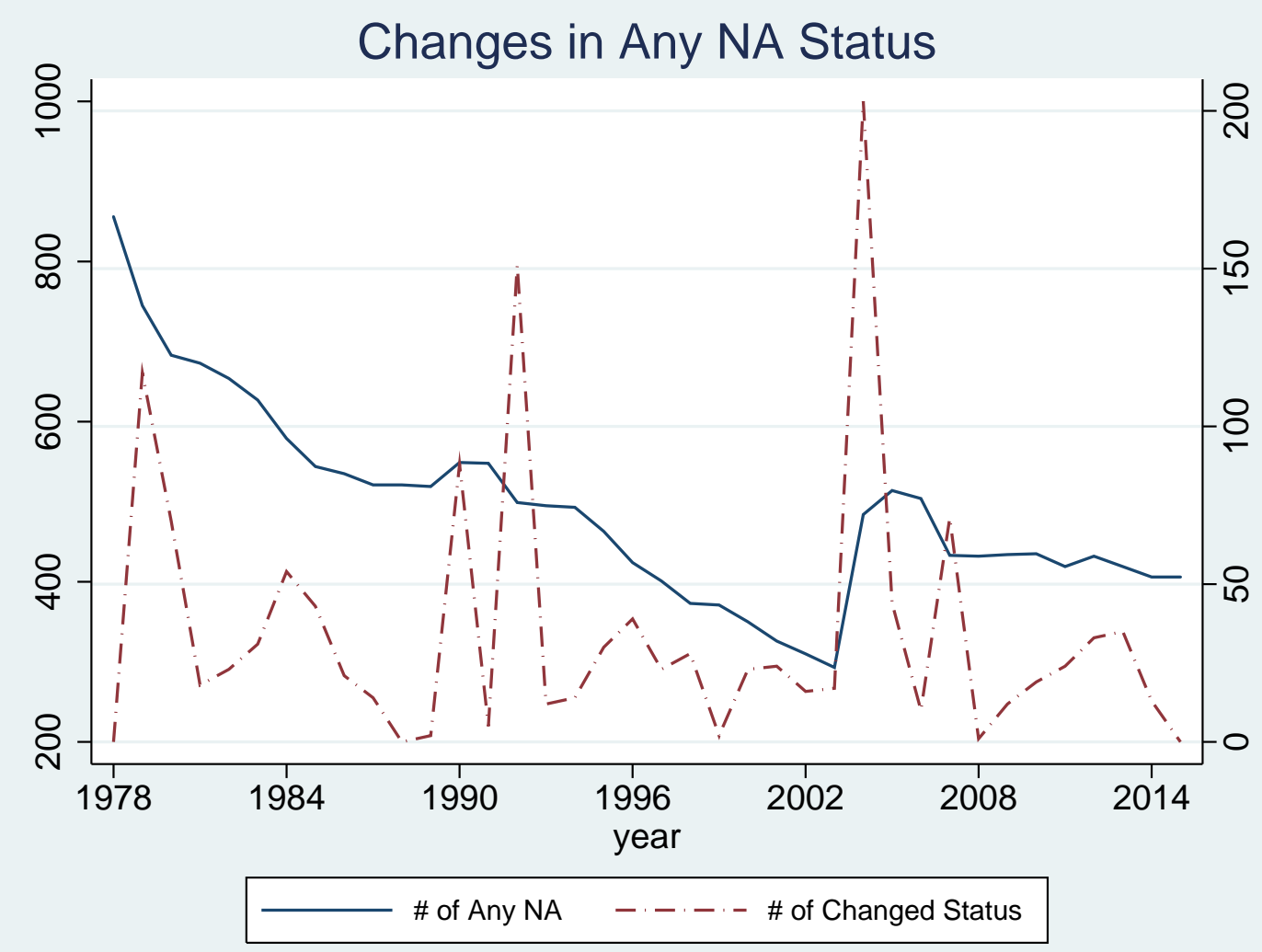

Figure 1. Number of Counties with Nonattainment Status and Number of Counties with Changed Status for Any Criteria Air Pollutants. (Note: the left Y axis is for the number of any NA, while the right $\mathrm{Y}$ axis is for the number of changed status.) 

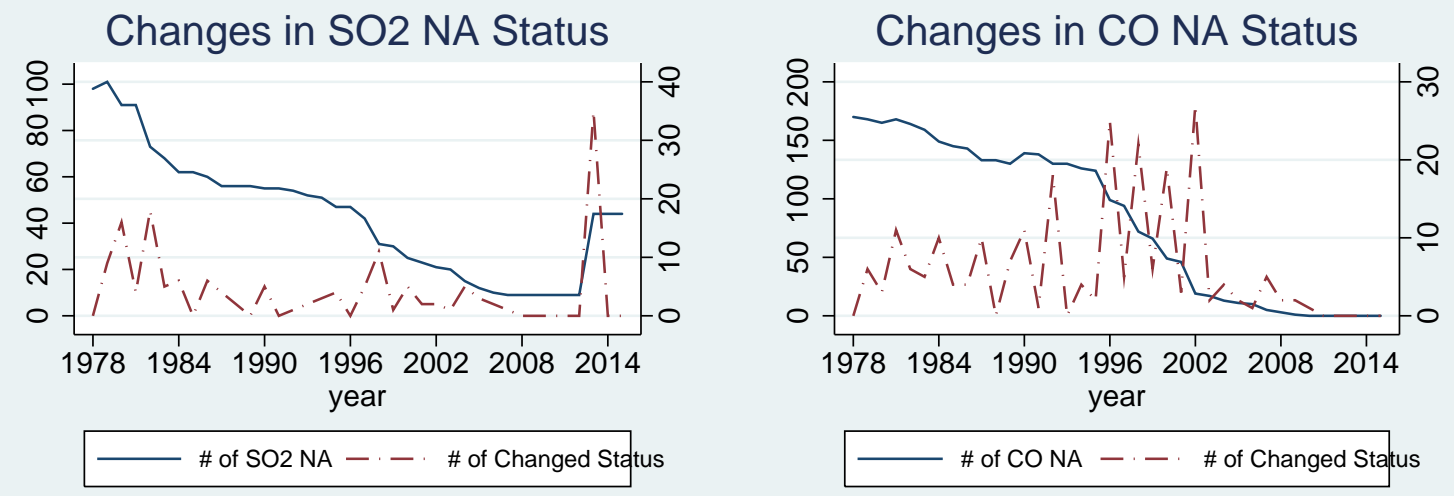

Changes in O3 NA Status

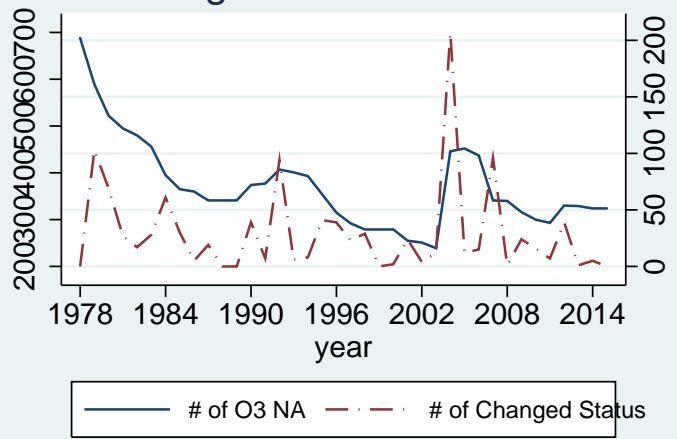

Changes in TSPs NA Status

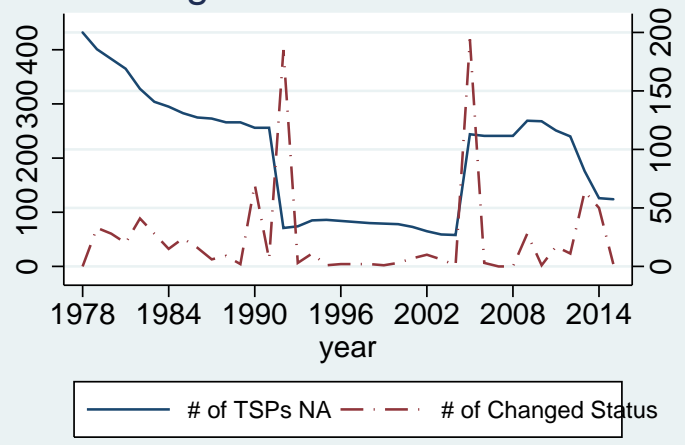

Figure 2. Number of Counties with Pollutant-Specific Nonattainment Status and Number of Counties with Changed Status. (Note: the number of pollutant-specific NA refers to the left Y axis, and the number of changed status refers to the right $\mathrm{Y}$ axis.) 

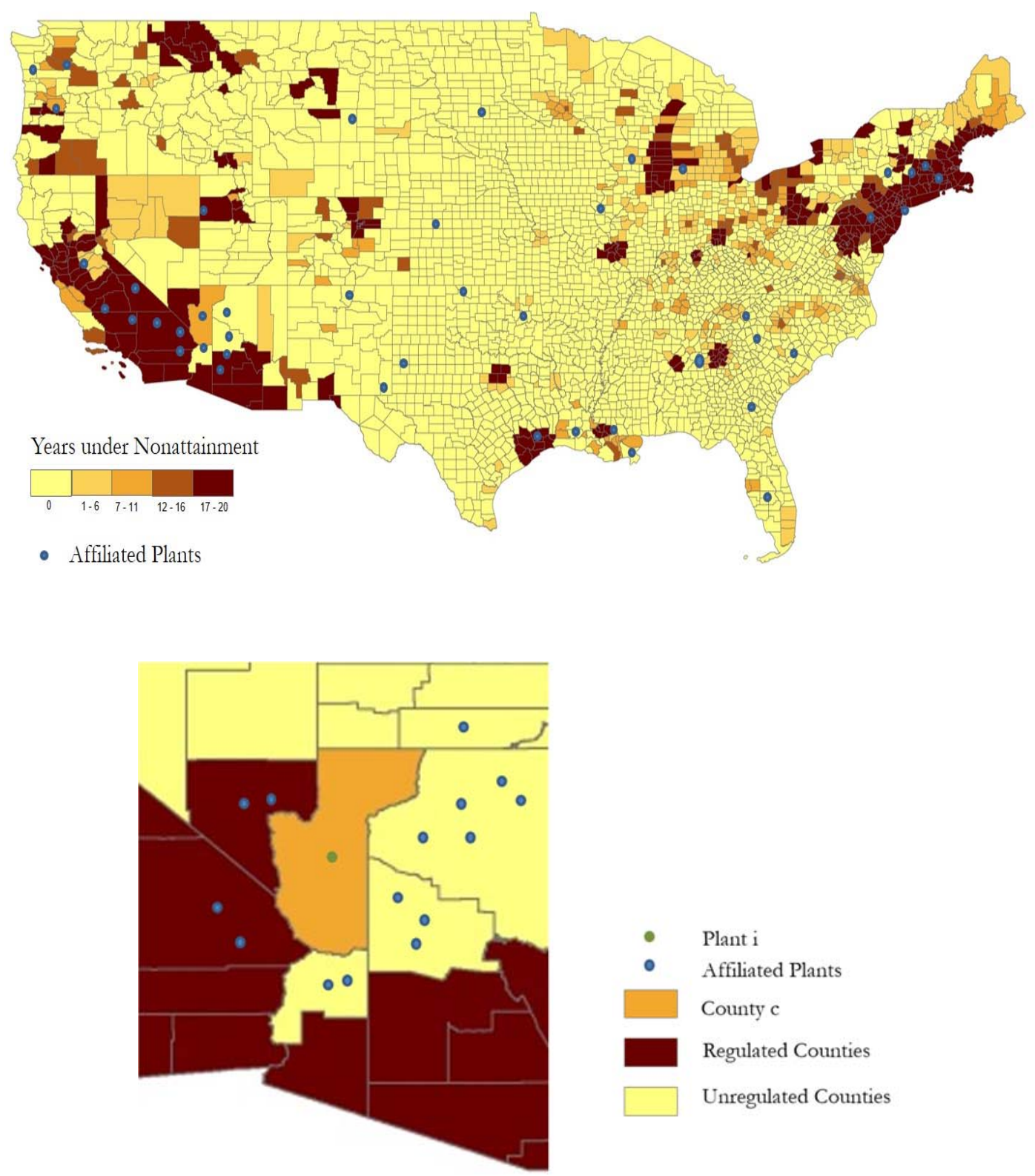

Regulated Counties

Unregulated Counties

Figure 3. Heuristic Map of Affiliated Plants. (Note: the upper chart depicts the location of some affiliated plants; the lower chart depicts the firm internal neighborhood network by exposure to regulation in terms of nonattainment designations.) 


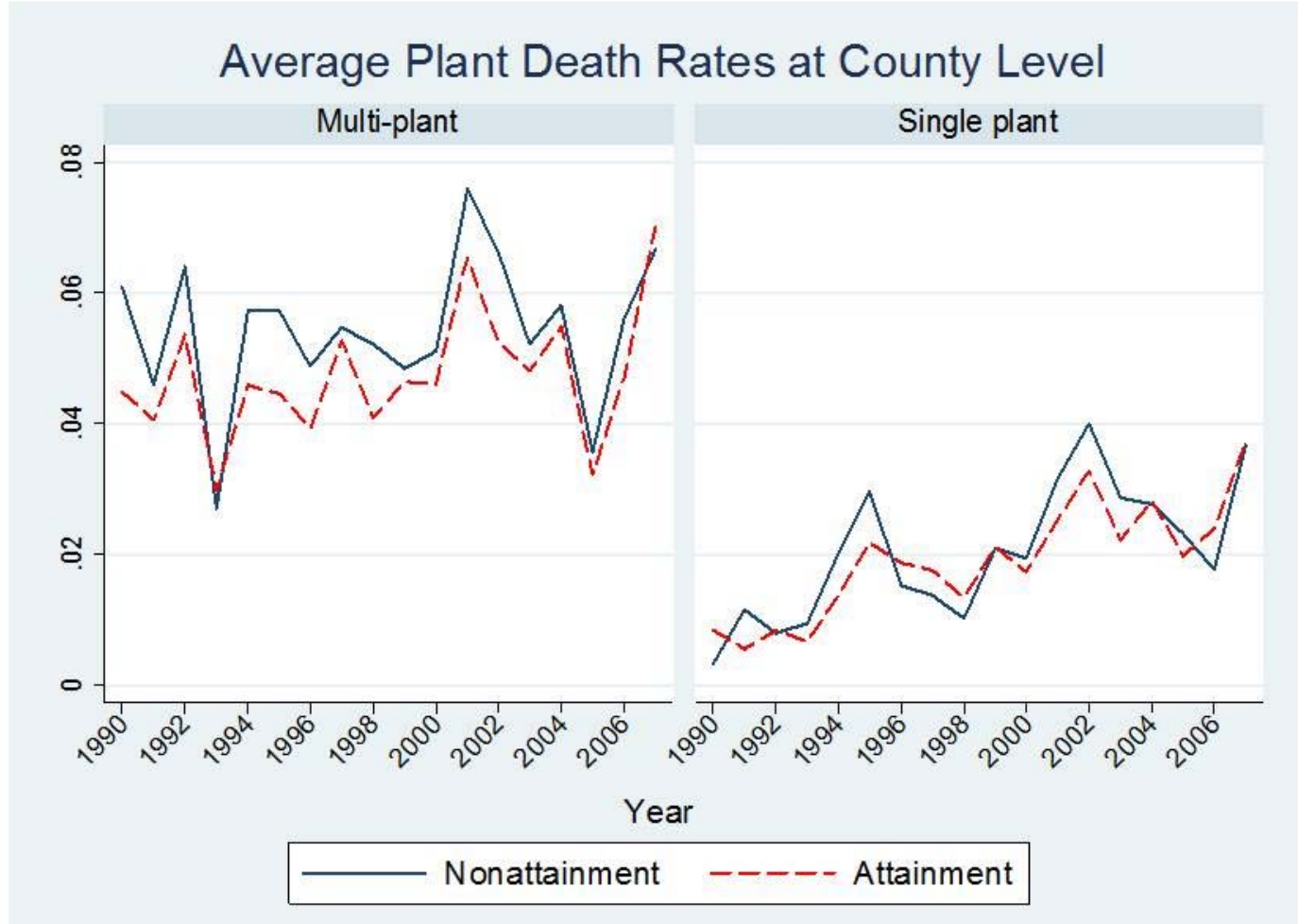

Figure 4. Average County-level Plant Death Rate by Multi-Plant Status, 1990-2008. (Note: death rate is computed as the number of death plants divided by the number of existing plants by multiplant status. Nonattainment is set for any criteria pollutants.) 
Table 1. Variable List

\begin{tabular}{|c|c|c|}
\hline Variable & Definition & Source/Explanation \\
\hline \multicolumn{3}{|c|}{ Plant Characteristics } \\
\hline Sales & value of deflated sales & NETS \\
\hline Employment & number of employment & NETS \\
\hline Labor productivity & value of deflated sales per labor employment & NETS, calculated \\
\hline Age & current year subtract first recorded year & NETS, calculated \\
\hline Export status & equals 1 if exports, and 0 otherwise & NETS \\
\hline Foreign ownership & equals 1 if owned by foreign firms, and 0 otherwise & NETS \\
\hline Multi-plant & $\begin{array}{l}\text { equals } 1 \text { if there exists one other plants with the same } \\
\text { headquarters, and } 0 \text { otherwise }\end{array}$ & NETS, calculated \\
\hline Death & equals 1 if current year is the last business year, 0 otherwise & NETS, calculated \\
\hline Takeover & equals 1 if it changes headquarters, and 0 otherwise & NETS, calculated \\
\hline Distance to Hdq & the log distance of a plan to headquarters & NETS, calculated \\
\hline Multi-industry & $\begin{array}{l}\text { the number of two-digit SIC industries in which } \\
\text { headquarters have plants }\end{array}$ & NETS, calculated \\
\hline LocalNet $_{i j c t}$ & $\begin{array}{l}\text { the (log) one plus the number of affiliated plants in county } \\
c \text { and industry } j \text { at time } t\end{array}$ & NETS, calculated \\
\hline$N b r N e t_{i j c t}$ & $\begin{array}{l}\text { the }(\log ) \text { one plus the number of affiliated plants in } \\
\text { counties sharing border with county } \mathrm{c} \text { and industry } j \text { at } t\end{array}$ & NETS, calculated \\
\hline WideNet $_{i j c t}$ & $\begin{array}{l}\text { the }(\log ) \text { one plus the number of affiliated plants in } \\
\text { industry } j \text { but outside or local and neighboring areas at } t \\
\text { the }(\log ) \text { one plus the number of affiliated plants in }\end{array}$ & NETS, calculated \\
\hline $\operatorname{RegNbrNet}_{i j c t}$ & $\begin{array}{l}\text { regulated counties sharing border with county } \mathrm{c} \text { and in } \\
\text { industry } j \text { at time } t\end{array}$ & NETS, calculated \\
\hline UnregNbrNet $_{i j c t}$ & $\begin{array}{l}\text { the }(\log ) \text { one plus the number of affiliated plants in } \\
\text { unregulated counties that share border with county } \mathrm{c} \text { and } \\
\text { in industry } \mathrm{j} \text { at time } \mathrm{t}\end{array}$ & NETS, calculated \\
\hline \multicolumn{3}{|c|}{ County Characteristics } \\
\hline Any Reg & equals 1 if NA for at least one pollutant, and 0 otherwise & EPA, calculated \\
\hline $\mathrm{SO}_{2} \mathrm{Reg}$ & equals 1 if $\mathrm{NA}$ for $\mathrm{SO}_{2}$, and 0 otherwise & EPA \\
\hline CO Reg & equals 1 if $\mathrm{NA}$ for $\mathrm{CO}$, and 0 otherwise & EPA \\
\hline $\mathrm{O}_{3} \mathrm{Reg}$ & equals 1 if $\mathrm{NA}$ for $\mathrm{O}_{3}$, and 0 otherwise & EPA \\
\hline TSPs Reg & equals 1 if NA for TSPs, and 0 otherwise & EPA \\
\hline Agglomeration & $\begin{array}{l}\text { the logarithm of one plus the number of plants outside of } \\
\text { its own internal network }\end{array}$ & CBP, calculated \\
\hline Property tax & median real estate tax rates in 2005 & ACS \\
\hline Road density & road length per land area & ArcGIS, calculated \\
\hline Unemployment rate & unemployment divided by labor force & BLS, calculated \\
\hline Industry-county wage & industry-specific annual payroll per employment & CBP, calculated \\
\hline \multicolumn{3}{|c|}{ Industry Characteristics } \\
\hline PPI & producer price index at two-digit SIC industry & BLS \\
\hline Entry & birth plants divided by total existing plants & Census of Bureau, \\
\hline Exit & death plants divided by total existing plants & Census of Bureau \\
\hline Sunk costs & $1-\min \{$ entry, exit $\}$ & $\begin{array}{l}\text { Bernard \& Jensen } \\
(2007) \text {, calculated }\end{array}$ \\
\hline
\end{tabular}


Table 2. Summary Statistics

\begin{tabular}{|c|c|c|c|c|c|c|}
\hline Variable & Mean & Std. dev. & Min & Max & $\begin{array}{l}\text { Multi- } \\
\text { plant } \\
\text { mean }\end{array}$ & $\begin{array}{l}\text { Single } \\
\text { plant } \\
\text { mean }\end{array}$ \\
\hline Deflated Sales & $18,579.51$ & $61,657.21$ & 0.00 & $5,353,243.00$ & $20,273.74$ & $10,597.12$ \\
\hline Employment & 151.10 & 456.60 & 1.00 & $30,000.00$ & 165.62 & 82.69 \\
\hline Sales per labor & 132.79 & $1,384.86$ & 0.00 & $332,752.30$ & 130.32 & 144.45 \\
\hline Age & 6.69 & 5.14 & 0.00 & 18.00 & 6.64 & 6.94 \\
\hline Death & 0.05 & 0.21 & 0.00 & 1.00 & 0.05 & 0.02 \\
\hline Birth & 0.05 & 0.21 & 0.00 & 1.00 & 0.05 & 0.04 \\
\hline Takeover & 0.46 & 0.50 & 0.00 & 1.00 & 0.44 & 0.56 \\
\hline Export status & 0.19 & 0.39 & 0.00 & 1.00 & 0.17 & 0.27 \\
\hline Foreign ownership & 0.16 & 0.36 & 0.00 & 1.00 & 0.17 & 0.09 \\
\hline Multi-industry & 3.05 & 2.76 & 1.00 & 17.00 & 3.49 & 1.00 \\
\hline$N_{i j c t}^{L}$ & 1.70 & 2.02 & 1.00 & 41.00 & 1.85 & 1.00 \\
\hline$N_{i j c t}^{N}$ & 0.56 & 1.81 & 0.00 & 44.00 & 0.68 & 0.00 \\
\hline$N_{i j c t}^{W}$ & 29.56 & 56.47 & 0.00 & 386.00 & 35.83 & 0.00 \\
\hline$N_{i j c t}^{R N}$ & 0.44 & 1.57 & 0.00 & 42.00 & 0.54 & 0.00 \\
\hline$N_{i j c t}^{U N}$ & 0.12 & 0.77 & 0.00 & 37.00 & 0.14 & 0.00 \\
\hline$N_{i j c t}^{R W}$ & 21.14 & 39.57 & 0.00 & 283.00 & 25.62 & 0.00 \\
\hline$N_{i j c t}^{U W}$ & 8.42 & 18.35 & 0.00 & 166.00 & 10.21 & 0.00 \\
\hline Any Reg & 0.56 & 0.49 & 0.00 & 1.00 & 0.55 & 0.61 \\
\hline $\mathrm{SO}_{2} \mathrm{Reg}$ & 0.04 & 0.18 & 0.00 & 1.00 & 0.04 & 0.03 \\
\hline CO Reg & 0.20 & 0.40 & 0.00 & 1.00 & 0.18 & 0.26 \\
\hline $\mathrm{O}_{3} \mathrm{Reg}$ & 0.50 & 0.50 & 0.00 & 1.00 & 0.49 & 0.55 \\
\hline TSPs Reg & 0.23 & 0.42 & 0.00 & 1.00 & 0.22 & 0.27 \\
\hline
\end{tabular}

Note: see text for all variable definitions. 
Table 3. Mean Value for Plant Characteristics by Firm Structure

\begin{tabular}{lcccc}
\hline Variable & \multicolumn{2}{c}{ Multi-plant } & \multicolumn{2}{c}{ Single plant } \\
& Any Reg $=0$ & Any Reg $=1$ & Any Reg $=0$ & Any Reg $=1$ \\
\hline Observations & 338,069 & 989,772 & 59,705 & 222,123 \\
Deflated sales & 21163.99 & 19969.66 & 12240.79 & 10155.31 \\
Employment & 171.26 & 163.70 & 92.68 & 80.00 \\
Sales per labor & 124.81 & 132.20 & 141.68 & 145.20 \\
Age & 7.24 & 6.43 & 7.85 & 6.70 \\
Death & 0.051 & 0.055 & 0.018 & 0.017 \\
Birth & 0.050 & 0.050 & 0.042 & 0.038 \\
Takeover & 0.445 & 0.434 & 0.593 & 0.545 \\
Export status & 0.171 & 0.173 & 0.268 & 0.268 \\
Foreign ownership & 0.166 & 0.171 & 0.101 & 0.085 \\
Multi-industry & 3.475 & 3.492 & 1.000 & 1.000 \\
$N_{i j c t}^{L}$ & 1.742 & 1.884 & 1.000 & 1.000 \\
$N_{i j c t}^{N}$ & 0.560 & 0.720 & 0.000 & 0.000 \\
$N_{i j c t}^{W}$ & 40.104 & 34.371 & 0.000 & 0.000 \\
$N_{i j c t}^{R N}$ & 0.208 & 0.649 & 0.000 & 0.000 \\
$N_{i j c t}^{U N}$ & 0.352 & 0.071 & 0.000 & 0.000 \\
$N_{i j c t}^{R W}$ & 27.742 & 24.896 & 0.000 & 0.000 \\
$N_{i j c t}^{U W}$ & 12.361 & 9.476 & 0.000 & 0.000 \\
\hline \hline
\end{tabular}

Note: see text for all variable definitions. 
Table 4. Dirty Industry List

\begin{tabular}{lcccc}
\hline \hline Industry (SIC codes) & $\mathrm{SO}_{2}$ & $\mathrm{CO}$ & $\mathrm{O}_{3}$ & TSPs \\
\hline Pulp and paper (2611-31) & $\mathrm{Y}$ & $\mathrm{Y}$ & $\mathrm{Y}$ & $\mathrm{Y}$ \\
Organic chemicals (2861-69) & & & $\mathrm{Y}$ & \\
Petroleum refining (2911) & $\mathrm{Y}$ & $\mathrm{Y}$ & $\mathrm{Y}$ & \\
Rubber and miscellaneous plastic products (30) & & & $\mathrm{Y}$ & \\
Stone, clay, glass and concrete (32) & $\mathrm{Y}$ & & $\mathrm{Y}$ & $\mathrm{Y}$ \\
Iron and steels (3312-25, 2231-2) & & $\mathrm{Y}$ & & \\
Nonferrous metals (333-34) & $\mathrm{Y}$ & $\mathrm{Y}$ & & \\
\hline \hline
\end{tabular}

Note: this industry classification is based on Greenstone (2002). 
Table 5. Baseline Effects Results of Probit Models on Plant Death

\begin{tabular}{|c|c|c|c|c|c|c|}
\hline \multirow[t]{2}{*}{ VARIABLES } & \multicolumn{4}{|c|}{ All sample } & \multirow{2}{*}{$\begin{array}{c}\text { Multi-plant } \\
\text { (5) }\end{array}$} & \multirow{2}{*}{$\begin{array}{c}\text { Single-plant } \\
\text { (6) }\end{array}$} \\
\hline & (1) & (2) & (3) & (4) & & \\
\hline Multi-plant status & $\begin{array}{c}0.0215^{* * *} \\
(0.0011)\end{array}$ & $\begin{array}{c}0.0216^{* * *} \\
(0.0011)\end{array}$ & $\begin{array}{c}0.0220^{* * *} \\
(0.0011)\end{array}$ & $\begin{array}{c}0.0214 * * * \\
(0.0011)\end{array}$ & & \\
\hline $\operatorname{Reg}_{c t-1}$ & $\begin{array}{c}-0.0027 * \\
(0.0016)\end{array}$ & $\begin{array}{l}-0.0020 \\
(0.0016)\end{array}$ & $\begin{array}{l}-0.0019 \\
(0.0016)\end{array}$ & $\begin{array}{l}-0.0019 \\
(0.0016)\end{array}$ & $\begin{array}{c}0.0014 * * \\
(0.0006)\end{array}$ & $\begin{array}{c}0.0006 \\
(0.0006)\end{array}$ \\
\hline $\operatorname{Reg}_{c t-1} \times$ Multi-plant & $\begin{array}{l}0.0030 * \\
(0.0016)\end{array}$ & $\begin{array}{c}0.0034 * * \\
(0.0016)\end{array}$ & $\begin{array}{c}0.0034 * * \\
(0.0016)\end{array}$ & $\begin{array}{c}0.0034 * * \\
(0.0016)\end{array}$ & & \\
\hline Size & $\begin{array}{c}-0.0020 * * * \\
(0.0001)\end{array}$ & $\begin{array}{c}-0.0023^{* * *} \\
(0.0001)\end{array}$ & $\begin{array}{c}-0.0019 * * * \\
(0.0001)\end{array}$ & $\begin{array}{c}-0.0023^{* * *} \\
(0.0001)\end{array}$ & $\begin{array}{c}-0.0029^{* * *} \\
(0.0001)\end{array}$ & $\begin{array}{c}-0.0005^{* * *} \\
(0.0002)\end{array}$ \\
\hline Labor productivity & $\begin{array}{c}-0.0033^{* * *} \\
(0.0004)\end{array}$ & $\begin{array}{c}-0.0061^{* * *} \\
(0.0005)\end{array}$ & $\begin{array}{c}-0.0046^{* * *} \\
(0.0004)\end{array}$ & $\begin{array}{c}-0.0061^{* * *} \\
(0.0005)\end{array}$ & $\begin{array}{c}-0.0069^{* * *} \\
(0.0006)\end{array}$ & $\begin{array}{c}-0.0029 * * * \\
(0.0004)\end{array}$ \\
\hline Age & $\begin{array}{c}-0.0075^{* * *} \\
(0.0002)\end{array}$ & $\begin{array}{c}-0.0084^{* * *} \\
(0.0003)\end{array}$ & $\begin{array}{c}-0.0094 * * * \\
(0.0003)\end{array}$ & $\begin{array}{c}-0.0084^{* * *} \\
(0.0003)\end{array}$ & $\begin{array}{c}-0.0106^{* * *} \\
(0.0003)\end{array}$ & $\begin{array}{c}-0.0012^{* *} \\
(0.0005)\end{array}$ \\
\hline Export Status & $\begin{array}{c}-0.0151^{* * *} \\
(0.0004)\end{array}$ & $\begin{array}{c}-0.0166^{* * *} \\
(0.0004)\end{array}$ & $\begin{array}{c}-0.0153^{* * *} \\
(0.0004)\end{array}$ & $\begin{array}{c}-0.0166^{* * *} \\
(0.0004)\end{array}$ & $\begin{array}{c}-0.0222^{* * *} \\
(0.0005)\end{array}$ & $\begin{array}{c}-0.0022^{* * *} \\
(0.0006)\end{array}$ \\
\hline Foreign Ownership & $\begin{array}{c}-0.0077 * * * \\
(0.0005)\end{array}$ & $\begin{array}{c}-0.0068^{* * *} \\
(0.0005)\end{array}$ & $\begin{array}{c}-0.0079 * * * \\
(0.0005)\end{array}$ & $\begin{array}{c}-0.0070^{* * *} \\
(0.0005)\end{array}$ & $\begin{array}{c}-0.0077 * * * \\
(0.0006)\end{array}$ & $\begin{array}{c}-0.0029 * * * \\
(0.0008)\end{array}$ \\
\hline Takeover & $\begin{array}{c}0.0063^{* * *} \\
(0.0004)\end{array}$ & $\begin{array}{c}0.0060^{* * *} \\
(0.0004)\end{array}$ & $\begin{array}{c}0.0064 * * * \\
(0.0004)\end{array}$ & $\begin{array}{c}0.0060^{* * *} \\
(0.0004)\end{array}$ & $\begin{array}{c}0.0076^{* * *} \\
(0.0005)\end{array}$ & $\begin{array}{c}0.0026^{* * *} \\
(0.0005)\end{array}$ \\
\hline Distance to Hdq & $\begin{array}{c}0.0032^{* * *} \\
(0.0001)\end{array}$ & $\begin{array}{c}0.0036^{* * *} \\
(0.0001)\end{array}$ & $\begin{array}{c}0.0034 * * * \\
(0.0001)\end{array}$ & $\begin{array}{c}0.0036 * * * \\
(0.0001)\end{array}$ & $\begin{array}{c}0.0042^{* * *} \\
(0.0001)\end{array}$ & \\
\hline Multi-industry & $\begin{array}{c}0.0014 * * * \\
(0.0001)\end{array}$ & $\begin{array}{c}0.0012^{* * *} \\
(0.0001)\end{array}$ & $\begin{array}{c}0.0015^{* * *} \\
(0.0001)\end{array}$ & $\begin{array}{c}0.0012^{* * *} \\
(0.0001)\end{array}$ & $\begin{array}{c}0.0014^{* * *} \\
(0.0001)\end{array}$ & \\
\hline LocalNet $_{i j c t}$ & $\begin{array}{c}0.0117 * * * \\
(0.0004)\end{array}$ & $\begin{array}{c}0.0134 * * * \\
(0.0005)\end{array}$ & $\begin{array}{c}0.0116^{* * *} \\
(0.0005)\end{array}$ & $\begin{array}{c}0.0136^{* * *} \\
(0.0005)\end{array}$ & $\begin{array}{c}0.0161 * * * \\
(0.0006)\end{array}$ & \\
\hline Agglomeration & $\begin{array}{c}-0.0007 * * \\
(0.0003)\end{array}$ & $\begin{array}{c}0.0014 * * * \\
(0.0004)\end{array}$ & $\begin{array}{c}0.0020 * * * \\
(0.0007)\end{array}$ & $\begin{array}{c}0.0024 * * * \\
(0.0007)\end{array}$ & $\begin{array}{c}0.0033 * * * \\
(0.0009)\end{array}$ & $\begin{array}{l}-0.0007 \\
(0.0010)\end{array}$ \\
\hline Property tax & $\begin{array}{c}0.0069 * * * \\
(0.0009)\end{array}$ & $\begin{array}{c}0.0013 \\
(0.0014)\end{array}$ & $\begin{array}{c}0.0013 \\
(0.0018)\end{array}$ & $\begin{array}{l}-0.0011 \\
(0.0018)\end{array}$ & $\begin{array}{l}-0.0019 \\
(0.0022)\end{array}$ & $\begin{array}{c}0.0012 \\
(0.0026)\end{array}$ \\
\hline Income per capita & $\begin{array}{l}-0.0001 \\
(0.0003)\end{array}$ & $\begin{array}{c}0.0021^{* * *} \\
(0.0004)\end{array}$ & $\begin{array}{c}0.0020^{* *} \\
(0.0008)\end{array}$ & $\begin{array}{c}0.0025^{* * *} \\
(0.0008)\end{array}$ & $\begin{array}{c}0.0034 * * * \\
(0.0010)\end{array}$ & $\begin{array}{l}-0.0011 \\
(0.0011)\end{array}$ \\
\hline Road density & $\begin{array}{c}0.0021^{* * *} \\
(0.0003)\end{array}$ & $\begin{array}{c}0.0029 * * * \\
(0.0003)\end{array}$ & $\begin{array}{c}0.0022^{* * *} \\
(0.0004)\end{array}$ & $\begin{array}{c}0.0018^{* * *} \\
(0.0004)\end{array}$ & $\begin{array}{c}0.0021 * * * \\
(0.0006)\end{array}$ & $\begin{array}{c}0.0009 \\
(0.0006)\end{array}$ \\
\hline Unemployment rate & $\begin{array}{l}-0.0001 \\
(0.0001)\end{array}$ & $\begin{array}{c}0.0008^{* * *} \\
(0.0001)\end{array}$ & $\begin{array}{c}0.0008^{* * *} \\
(0.0001)\end{array}$ & $\begin{array}{c}0.0007 * * * \\
(0.0001)\end{array}$ & $\begin{array}{c}0.0009 * * * \\
(0.0002)\end{array}$ & $\begin{array}{c}0.0002 \\
(0.0002)\end{array}$ \\
\hline Industry-county wage & $\begin{array}{c}0.0106^{* * *} \\
(0.0010)\end{array}$ & $\begin{array}{c}0.0047 * * * \\
(0.0011)\end{array}$ & $\begin{array}{c}0.0023^{*} \\
(0.0012)\end{array}$ & $\begin{array}{c}0.0044 * * * \\
(0.0012)\end{array}$ & $\begin{array}{c}0.0052^{* * *} \\
(0.0015)\end{array}$ & $\begin{array}{c}0.0004 \\
(0.0017)\end{array}$ \\
\hline Industry sunk costs & $\begin{array}{c}-0.1392^{* * * *} \\
(0.0110)\end{array}$ & $\begin{array}{c}0.0108 \\
(0.0241)\end{array}$ & $\begin{array}{c}-0.1132^{* * *} \\
(0.0120)\end{array}$ & $\begin{array}{c}0.0095 \\
(0.0241)\end{array}$ & $\begin{array}{l}-0.0073 \\
(0.0299)\end{array}$ & $\begin{array}{l}0.0592^{*} \\
(0.0313)\end{array}$ \\
\hline
\end{tabular}




\begin{tabular}{lcccccc} 
Observations & $1,239,824$ & $1,181,595$ & $1,181,641$ & $1,181,595$ & 971,754 & 243,273 \\
Pseudo R-squared & 0.0353 & 0.0461 & 0.0420 & 0.0465 & 0.0313 & 0.0386 \\
\hline Year FE & $\mathrm{N}$ & $\mathrm{Y}$ & $\mathrm{Y}$ & $\mathrm{Y}$ & $\mathrm{Y}$ & $\mathrm{Y}$ \\
Industry FE & $\mathrm{N}$ & $\mathrm{Y}$ & $\mathrm{N}$ & $\mathrm{Y}$ & $\mathrm{Y}$ & $\mathrm{Y}$ \\
State FE & $\mathrm{N}$ & $\mathrm{N}$ & $\mathrm{Y}$ & $\mathrm{Y}$ & $\mathrm{Y}$ & $\mathrm{Y}$ \\
\hline \hline
\end{tabular}

Note: Dependent variable is a binary indicator of plant death. The coefficients give the marginal effect of changing the independent variable estimated from probit models. See Table 2 and the text for variable definitions. All control variables, except indicator variables, are in logs. Standard errors presented in the parentheses are clustered at county level. Industry dummies are calculated at the three-digit SIC level. *** significant at $1 \%$ level, $* *$ significant at $5 \%$ level, * significant at $10 \%$ level. 
Table 6. Regional Firm Internal Network Effect on Plant Death

\begin{tabular}{lcccc}
\hline \hline VARIABLES & $(1)$ & $(2)$ & $(3)$ & $(4)$ \\
\hline & & & & \\
Dirty $_{j} \times$ Reg $_{c t-1} \times$ LocalNet $_{i j c t-1}$ & 0.0130 & & & -0.0080 \\
& $(0.0314)$ & & & $(0.0330)$ \\
Dirty $_{j} \times$ Reg $_{c t-1} \times$ NbrNet $_{i j c t-1}$ & & $0.0450^{* *}$ & & $0.0469^{*}$ \\
& & $(0.0224)$ & & $(0.0240)$ \\
Dirty $_{j} \times$ Reg $_{c t-1} \times$ WideNet $_{i j c t-1}$ & & & 0.0044 & 0.0013 \\
& & & $(0.0064)$ & $(0.0067)$ \\
& & & & \\
Observations & & & 971,754 & 971,754 \\
Pseudo R-squared & 971,754 & 971,754 & 0.0341 & 0.0341 \\
Plant Control & 0.0341 & 0.0341 & $\mathrm{Y}$ & $\mathrm{Y}$ \\
Year FE & $\mathrm{Y}$ & $\mathrm{Y}$ & $\mathrm{Y}$ & $\mathrm{Y}$ \\
3SIC-Industry Trend & $\mathrm{Y}$ & $\mathrm{Y}$ & $\mathrm{Y}$ & $\mathrm{Y}$ \\
State Trend & $\mathrm{Y}$ & $\mathrm{Y}$ & $\mathrm{Y}$ & $\mathrm{Y}$ \\
\hline \hline
\end{tabular}

Note: Dependent variable is a binary indicator of plant death. All controls and fixed effects in column 5 of Table 5 are included. Dirty is a dirty industry dummy for any criteria air pollutants. See text for all variable definitions. Standard errors presented in the parentheses are clustered at county level. *** significant at $1 \%$ level, ${ }^{* *}$ significant at $5 \%$ level, * significant at $10 \%$ level. 
Table 7. Regional Firm Internal Network Effect by Exposure to Regulation

\begin{tabular}{|c|c|c|c|}
\hline \multirow[t]{2}{*}{ VARIABLES } & \multicolumn{3}{|c|}{ Whole period of $1990-2008$} \\
\hline & (1) & (2) & (3) \\
\hline \multirow{2}{*}{$\operatorname{Dirty}_{j} \times \operatorname{Reg}_{c t-1} \times \operatorname{RegNbrNet}_{i j c t-1}$} & 0.0024 & & 0.0134 \\
\hline & $(0.0297)$ & & $(0.0298)$ \\
\hline \multirow{2}{*}{$\operatorname{Dirty}_{j} \times \operatorname{Reg}_{c t-1} \times$ UnregNbrNet $_{i j c t-1}$} & $0.0909 * *$ & & $0.0999 * * *$ \\
\hline & $(0.0359)$ & & $(0.0366)$ \\
\hline \multirow[t]{2}{*}{$\operatorname{Dirty}_{j} \times \operatorname{Reg}_{c t-1} \times \operatorname{RegWideNet}_{i j c t-1}$} & & $-0.0279 * * *$ & $-0.0274^{* * *}$ \\
\hline & & $(0.0089)$ & $(0.0090)$ \\
\hline \multirow{2}{*}{ Dirty $_{j} \times \operatorname{Reg}_{c t-1} \times$ UnregWideNet $_{i j c t-1}$} & & 0.0142 & 0.0119 \\
\hline & & $(0.0102)$ & $(0.0101)$ \\
\hline Observations & 971,754 & 971,754 & 971,754 \\
\hline Pseudo R-squared & 0.0341 & 0.0342 & 0.0343 \\
\hline Plant Control & $\mathrm{Y}$ & $\mathrm{Y}$ & $\mathrm{Y}$ \\
\hline Year FE & $\mathrm{Y}$ & $\mathrm{Y}$ & Y \\
\hline 3SIC-Industry Trend & $\mathrm{Y}$ & $\mathrm{Y}$ & $\mathrm{Y}$ \\
\hline State Trend & $\mathrm{Y}$ & $\mathrm{Y}$ & $\mathrm{Y}$ \\
\hline
\end{tabular}

Note: Dependent variable is a binary indicator of plant death. For each column, the coefficients give the marginal effect of changing the independent variable estimated from probit models. All controls and fixed effects in column 5 of Table 5 are included. See text for all variable definitions. Standard errors presented in the parentheses are clustered at county level. ${ }^{* * *}$ significant at $1 \%$ level, ${ }^{* *}$ significant at $5 \%$ level, ${ }^{*}$ significant at $10 \%$ level. 
Table 8. Robustness Checks - Sample Periods

\begin{tabular}{|c|c|c|c|c|c|c|}
\hline \multirow[t]{2}{*}{ VARIABLES } & \multicolumn{3}{|c|}{ "Post-CAAA period of 1990-1999 } & \multicolumn{3}{|c|}{ "New standard period of $2000-2008$} \\
\hline & $(1)$ & $(2)$ & (3) & (4) & (5) & $(6)$ \\
\hline \multirow{2}{*}{$\operatorname{Dirty}_{j} \times \operatorname{Reg}_{c t-1} \times \operatorname{RegNbrNet}_{i j c t-1}$} & -0.0005 & & 0.0126 & 0.0103 & & 0.0198 \\
\hline & $(0.0473)$ & & $(0.0474)$ & $(0.0377)$ & & $(0.0381)$ \\
\hline \multirow{2}{*}{ Dirty $_{j} \times \operatorname{Reg}_{c t-1} \times$ UnregNbrNet $_{i j c t-1}$} & $0.1103^{*}$ & & $0.1123^{*}$ & $0.0890^{* *}$ & & $0.1011 * *$ \\
\hline & $(0.0643)$ & & $(0.0649)$ & $(0.0427)$ & & $(0.0434)$ \\
\hline \multirow[t]{2}{*}{ Dirty $_{j} \times \operatorname{Reg}_{c t-1} \times \operatorname{RegWideNet}_{i j c t-1}$} & & $-0.0359 * * *$ & $-0.0340 * * *$ & & -0.0172 & -0.0189 \\
\hline & & $(0.0117)$ & $(0.0118)$ & & $(0.0138)$ & $(0.0140)$ \\
\hline \multirow[t]{2}{*}{ Dirty $_{j} \times \operatorname{Reg}_{c t-1} \times$ UnregWideNet $_{i j c t-1}$} & & 0.0221 & 0.0223 & & 0.0051 & 0.0014 \\
\hline & & $(0.0143)$ & $(0.0144)$ & & $(0.0157)$ & $(0.0156)$ \\
\hline Observations & 499,887 & 499,887 & 499,887 & 471,867 & 471,867 & 471,867 \\
\hline Pseudo R-squared & 0.0438 & 0.0440 & 0.0441 & 0.0306 & 0.0307 & 0.0307 \\
\hline Plant Control & $\mathrm{Y}$ & $\mathrm{Y}$ & $\mathrm{Y}$ & $\mathrm{Y}$ & $\mathrm{Y}$ & $\mathrm{Y}$ \\
\hline Year FE & $\mathrm{Y}$ & $\mathrm{Y}$ & $\mathrm{Y}$ & $\mathrm{Y}$ & $\mathrm{Y}$ & $\mathrm{Y}$ \\
\hline 3SIC-Industry Trend & $\mathrm{Y}$ & $\mathrm{Y}$ & $\mathrm{Y}$ & $\mathrm{Y}$ & $\mathrm{Y}$ & $\mathrm{Y}$ \\
\hline State Trend & Y & Y & $\mathrm{Y}$ & $\mathrm{Y}$ & $\mathrm{Y}$ & $\mathrm{Y}$ \\
\hline
\end{tabular}

Note: Dependent variable is a binary indicator of plant death. For each column, the coefficients give the marginal effect of changing the independent variable estimated from probit models. All controls and fixed effects in column 5 of Table 5 are included. Dirty is a dirty industry dummy for any criteria air pollutants. See text for all variable definitions. Standard errors presented in the parenthesis are clustered at county level. *** significant at $1 \%$ level, ** significant at $5 \%$ level, * significant at $10 \%$ level. 
Table 9: Robustness Check - Pollutant-specific Dirty Emitter

\begin{tabular}{|c|c|c|c|c|}
\hline \multirow[t]{2}{*}{ VARIABLES } & \multicolumn{4}{|c|}{ Whole sample period } \\
\hline & $\mathrm{SO}_{2}$ & $\mathrm{CO}$ & $\mathrm{O}_{3}$ & TSPs \\
\hline \multirow[t]{2}{*}{$\operatorname{Dirty}_{p} \times \operatorname{Reg}_{c p t-1} \times \operatorname{RegNbrNet}_{i j c t-1}$} & -0.0260 & -0.0693 & 0.0154 & $-0.0686^{* *}$ \\
\hline & $(0.0734)$ & $(0.0615)$ & $(0.0181)$ & $(0.0297)$ \\
\hline \multirow[t]{2}{*}{ Dirty $_{p} \times$ Reg $_{c p t-1} \times$ UnregNbrNet $_{i j c t-1}$} & -0.0744 & $0.4043 *$ & $0.1570^{* * *}$ & 0.0447 \\
\hline & $(0.1073)$ & $(0.2113)$ & $(0.0555)$ & $(0.1177)$ \\
\hline \multirow[t]{2}{*}{$\operatorname{Dirty}_{p} \times \operatorname{Reg}_{c p t-1} \times \operatorname{RegWideNet}_{i j c t-1}$} & -0.0645 & 0.0185 & $-0.0272 * * *$ & -0.0063 \\
\hline & $(0.0411)$ & $(0.0346)$ & $(0.0097)$ & $(0.0218)$ \\
\hline \multirow{2}{*}{ Dirty $_{p} \times \operatorname{Reg}_{c p t-1} \times$ UnregWideNet $_{i j c t-1}$} & $0.0872 *$ & -0.0435 & 0.0105 & 0.0136 \\
\hline & $(0.0469)$ & $(0.0396)$ & $(0.0112)$ & $(0.0256)$ \\
\hline Observations & 971,754 & 971,754 & 971,754 & 971,754 \\
\hline Pseudo R-squared & 0.0343 & 0.0342 & 0.0342 & 0.0342 \\
\hline Plant Control & $\mathrm{Y}$ & $\mathrm{Y}$ & Y & $\mathrm{Y}$ \\
\hline Year FE & $\mathrm{Y}$ & $\mathrm{Y}$ & $\mathrm{Y}$ & $\mathrm{Y}$ \\
\hline 3SIC-Industry Trend & $\mathrm{Y}$ & $\mathrm{Y}$ & $\mathrm{Y}$ & $\mathrm{Y}$ \\
\hline State Trend & $\mathrm{Y}$ & $\mathrm{Y}$ & $\mathrm{Y}$ & $\mathrm{Y}$ \\
\hline
\end{tabular}

Note: Dependent variable is a binary indicator of plant death. For each column, the coefficients give the marginal effect of changing the independent variable estimated from probit models. All controls and fixed effects in column 5 of Table 5 are included. Dirty is a dirty industry dummy for any criteria air pollutants. See text for all variable definitions. Standard errors presented in the parentheses are clustered at county level. *** significant at $1 \%$ level, ** significant at $5 \%$ level, * significant at $10 \%$ level. 
Table 10. Linear Probability Model for Plant Death

\begin{tabular}{|c|c|c|c|c|c|c|}
\hline \multirow[t]{2}{*}{ VARIABLES } & \multicolumn{6}{|c|}{ Whole sample period } \\
\hline & $(1)$ & $(2)$ & (3) & (4) & $(5)$ & (6) \\
\hline \multirow{2}{*}{$\operatorname{Dirty}_{j} \times \operatorname{Reg}_{c t-1} \times \operatorname{RegNbrNet}_{i j c t-1}$} & 0.0001 & 0.0015 & & & 0.0014 & 0.0032 \\
\hline & $(0.0029)$ & $(0.0046)$ & & & $(0.0030)$ & $(0.0047)$ \\
\hline \multirow{2}{*}{ Dirty $_{j} \times \operatorname{Reg}_{c t-1} \times$ UnregNbrNet $_{i j c t-1}$} & $0.0098^{* * *}$ & $0.0096^{*}$ & & & $0.0110^{* * *}$ & $0.0114^{* *}$ \\
\hline & $(0.0036)$ & $(0.0052)$ & & & $(0.0037)$ & $(0.0053)$ \\
\hline \multirow[t]{2}{*}{$\operatorname{Dirty}_{j} \times \operatorname{Reg}_{c t-1} \times \operatorname{RegWideNet}_{i j c t-1}$} & & & $-0.0029 * * *$ & 0.0009 & $-0.0029 * * *$ & $-0.0022^{* *}$ \\
\hline & & & $(0.0010)$ & $(0.0015)$ & $(0.0010)$ & $(0.0010)$ \\
\hline \multirow{2}{*}{ Dirty $_{j} \times \operatorname{Reg}_{c t-1} \times$ UnregWideNet $_{i j c t-1}$} & & & 0.0014 & $-0.0035^{* *}$ & 0.0012 & -0.0027 \\
\hline & & & $(0.0011)$ & $(0.0016)$ & $(0.0011)$ & $(0.0047)$ \\
\hline Observations & $1,021,884$ & $1,021,884$ & $1,021,884$ & $1,021,884$ & $1,021,884$ & $1,021,884$ \\
\hline Adjusted R-squared & 0.0165 & 0.2528 & 0.0166 & 0.2528 & 0.0166 & 0.2528 \\
\hline Plant Control & $\mathrm{Y}$ & $\mathrm{Y}$ & $\mathrm{Y}$ & $\mathrm{Y}$ & $\mathrm{Y}$ & $\mathrm{Y}$ \\
\hline Year FE & $\mathrm{Y}$ & $\mathrm{Y}$ & $\mathrm{Y}$ & $\mathrm{Y}$ & $\mathrm{Y}$ & $\mathrm{Y}$ \\
\hline 3SIC-Industry Trend & $\mathrm{Y}$ & $\mathrm{Y}$ & $\mathrm{Y}$ & $\mathrm{Y}$ & $\mathrm{Y}$ & $\mathrm{Y}$ \\
\hline State Trend & Y & $\mathrm{Y}$ & Y & Y & Y & Y \\
\hline County FE & Y & & Y & & Y & \\
\hline Plant FE & & $\mathrm{Y}$ & & $\mathrm{Y}$ & & $\mathrm{Y}$ \\
\hline
\end{tabular}

Note: Dependent variable is a binary indicator of plant death. For each column, the coefficients give the marginal effect of changing the independent variable estimated from probit models. All controls and fixed effects in column 5 of Table 5 are included. See text for all variable definitions. Standard errors presented in the parentheses are clustered at county level. *** significant at $1 \%$ level, ** significant at $5 \%$ level, * significant at $10 \%$ level. 


\section{Appendix}

This appendix describes detailed algorithm for matching plant-level data from different sources. We begin with polluting plants reported in the NEI database of the EPA. The NEI database contains information about plants that emit criteria air pollutants for all areas of the United States. Since 2002, it releases an updated version of the NEI database every three years with the latest version realeased in 2008. Plants recorded in the NEI database emit at least one type of criteria air pollutant (i.e., CO, SO2, TSPs, NOx, and VOCs).

Next, we match polluting plants in the NEI database with those that appear in the NETS database, using a name and plant identifier matching algorithm. The NETS database assigns the DUNS number to identify unique business facilities. The EPA also has information of DUNS numbers for some polluting plants, but not all. Approximately $80 \%$ of polluting plants in the manufacturing industry collected in the NEI database have associated DUNS numbers. However, the EPA does not provide further information about how DUNS numbers are reported for polluting plants and why some plants have missing DUNS numbers while others have more than one. In an attempt to circumvent this shortcoming, we consider a pair of plants from each source as a match, if the following series of criteria are satisfied. They must share the same DUNS number and are located in the same county. More importantly, for each pair, we check the plant names from each source to ensure a match. In the end, this matching procedure narrows to 18,743 unique polluting plants, roughly half of manufacturing polluters reported in the NEI database prior to matching.

We then take these 18,743 matched polluting plants into the NETS database to search for their related plants, which are affiliated with the same parent company (i.e., headquarters). For each plant, the NETS reports information about its headquarters (e.g., the DUNS number, name, and location). In addition, it tracks the headquarters' DUNS number over the study period. Plants related to the matched polluters that appear in the NEI database are found in the NETS database through the headquarters' DUNS numbers. We restrict our sample to plants in the manufacturing industry as determined by four-digit SIC codes (between 2000 and 4000). As a consequence, we are left with 1,610,462 plant-by-year observations from 1990 to 2008, which gives us 153,582 unique plants

affiliated with 44,069 unique headquarters. Note that the number of headquarters is larger than the number of polluting plants because, during the study period, some plants changed headquarters, thereby bringing more headquarters and even more affiliated plants to the sample search. 